\section{D) Check for updates}

Cite this: Dalton Trans., 2020, 49 15339

Received 22nd September 2020, Accepted 19th October 2020

DOI: 10.1039/d0dt03298k

rsc.li/dalton

\title{
Chelated Fischer carbene complexes of annulated thiophenes: synthesis, structure and electrochemistry $\dagger$
}

\author{
Zandria Lamprecht, (D) ${ }^{a}$ Frederick P. Malan, (D) ${ }^{a}$ Israel Fernández, (DD ${ }^{\mathrm{b}}$ Simon Lotz ${ }^{\mathrm{a}}$ \\ and Daniela I. Bezuidenhout (D) *c
}

\begin{abstract}
Two (thieno[3,2-b]thiophene) and three annulated thiophenes (dithieno[2,3-b; $\left.3^{\prime}, 2^{\prime}-d\right]$ thiophene and dithieno[3,2-b;2', $\left.3^{\prime}-d\right]$ thiophene) were employed as building blocks to synthesize linear or semi-circular chelated mononuclear biscarbene and dinuclear tetracarbene complexes. The electronic properties of the annulated thienylene chelated carbene complexes were investigated by cyclic voltammetry experiments and compared to non-chelated Fischer-type monocarbene complexes. Density functional theory (DFT) calculations were used to assign the redox events and to probe the extent of electron delocalisation as well as the possibility of electronic (intramolecular metal-metal) communication as a result of intervalence. The differences of these electronic properties in the conjugated chelated carbene complexes are compared to chelated carbene compounds without a linear conjugated pathway.
\end{abstract}

\section{Introduction}

Thiophene oligomers (and polymers) are widely studied because of their electroconductive and photonic properties. ${ }^{1-14}$ Application of $\alpha$-connected, conjugated thiophene units in chain stuctures ${ }^{1,5-7}$ and $\alpha, \beta$-fused thiophene rings in band structures $^{1,2,4,8-12}$ are finding wide application as organic conductors/superconductors ${ }^{4,7,8}$ and non-linear optical materials. ${ }^{1,5,6,9}$ In addition, oligothiophenes are appealing units to act as spacer-ligands between metal fragments for potential long distance metal-metal communication., ${ }^{3,13,14}$ Electron excessive thiophene donors and strong electron-withdrawing Fischer carbene carbon acceptors arranged in a 'push-pull' fashion via a conjugated pathway are conducive to electron transfer and polarisation processes with potentially diverse electronic applications.

\footnotetext{
${ }^{a}$ Department of Chemistry, University of Pretoria, Private Bag X20, Hatfield 0028, Pretoria, South Africa

${ }^{b}$ Departamento de Quimica Orgánica I and Centro de Innovación en Quimica Avanzada (ORFEO-CINQA), Facultad de Ciencias Químicas, Universidad Complutense de Madrid, 28040 Madrid, Spain

${ }^{c}$ Laboratory of Inorganic Chemistry, Environmental and Chemical Engineering, University of Oulu, P. O. Box 3000, 90014 Oulu, Finland.

E-mail: daniela.bezuidenhout@oulu.fi

$\dagger$ Electronic supplementary information (ESI) available: Synthesis details, NMR and FT-IR spectra, crystal data collection and crystal packing details and cartesian coordinates for optimized geometries. CCDC 2032754-2032759. For ESI and crystallographic data in CIF or other electronic format see DOI: 10.1039/ d0dt03298k
}

Unlike chelated N-heterocyclic biscarbene complexes, chelated Fischer carbene complexes (FCCs) reported in the literature are more rare. ${ }^{15-31}$ Dinuclear chelated tetracarbene complexes could be prepared utilising thiophene or thieno $[2,3-b]$ thiophene if the tetrabrominated thienyl substrates were employed as starting materials. ${ }^{25,32}$ Both chelated mononuclear biscarbene and dinuclear tetracarbene complexes were isolated, as well as the intermediate dinuclear triscarbene complex (with a monocarbene ligand on one metal terminal, and a chelated biscarbene metal carbonyl group on the other side of the spacer thienothiophene with the sulphur atoms both orientated in the same (cis) direction, up-up), Fig. 1. The tetracarbene complex, due to the curved nature of the thienothiophene backbone, displayed extreme steric congestion of the two adjacent ethoxy carbene substituents resulting in an accompanying deviation from planarity.

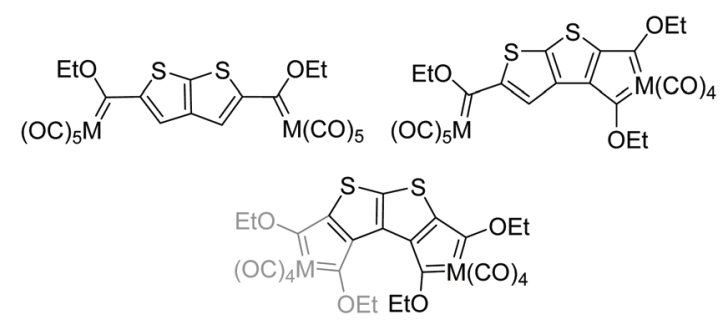

Fig. 1 Bis-, tris- and tetracarbene complexes reported using tetrabromothieno[2,3-b]thiophene as precursor. 
In this study, two fused thiophenes (thieno[3,2- $b]$ thiophene (trans-TT)) and three annulated thiophenes (dithieno[2,3$\left.b ; 3^{\prime}, 2^{\prime}-d\right]$ thiophene (cis-DTT) and dithieno[3,2- $\left.b ; 2^{\prime}, 3^{\prime}-d\right]$ thiophene (trans-DTT)), are employed as building blocks to synthesize chelated FCCs. For trans-TT and trans-DTT the sulphur atom orientations are in up-down and up-down-up positions, respectively, and expected to give linearly arranged bands of chelated tetracarbene complexes. For comparison, the synthesis and structure of FCCs with the curved cis-DTT isomer with sulphur atoms in an up-up-up orientation, is also investigated. The effect of the conjugation pathway in the different annulated (di)thienothienyl carbene substituents, the number of annulated thienylene rings and the effect of carbene chelation on the electrochemistry of the resultant complexes are investigated.

\section{Results and discussion}

\section{Synthesis of chelated carbene complexes}

The synthesis of the chelated carbene complexes from thienylene substrates requires activation of both the $\alpha-\left(\mathrm{C} 5\right.$ and $\left.\mathrm{C} 5{ }^{\prime}\right)$ and $\beta$-positions ( $\mathrm{C} 4$ and $\mathrm{C}^{\prime}$ ) of the annulated thiophenes by preparing the tetrabromothienylene derivatives as starting materials. ${ }^{25}$ The $\alpha$-positions are generally more reactive compared to the $\beta$-positions, allowing some control during a selective step-wise lithiation procedure. The aim of the method in this study is to produce bischelated dimetal tetracarbene complexes, hence the experimental conditions were selected to target these complexes. For annulated thiophene rings this would mean utilizing all available sites for carbene formation. The first dilithiation at $\mathrm{C} 5$ and $\mathrm{C5}^{\prime}$, at a sufficiently low temperature with $n$-BuLi, leaves $\mathrm{C} 4$ and $\mathrm{C}^{\prime}$ unaffected. Two equivalents of metal hexacarbonyl are added, permitting nucleophilic attack of the dianions on carbonyl carbon atoms of the metal hexacarbonyls, leading to the formation of a C5,C5' diacyl-dimetallate. Charge delocalisation in the two substituents, from the metals to oxygens, protects the acyl carbons against further nucleophilic attack. Dilithiation via lithium-halogen exchange of the remaining two sites, $\mathrm{C} 4$ and $\mathrm{C} 4$ ', followed by in situ reaction with two cis carbonyl ligands of the already coordinated metal carbonyl moieties, afford, after alkylation, the dinuclear tetracarbene complex. Alkylations during chelated carbene complex synthesis, are carried out using a large excess of $\left[\mathrm{Et}_{3} \mathrm{O}\right]\left[\mathrm{BF}_{4}\right]$, as extra alkylating agent facilitates the removal of remaining bromines from intermediates. ${ }^{33,34}$ The reactions are illustrated in Scheme 1.

In reactions (a) and (b) (Scheme 1), trans-TT-Br ${ }_{4}$ is used as the starting material, with either chromium (a) or tungsten hexacarbonyl (b) as metal precursors (Scheme 1). The mononuclear chelated biscarbene complexes, $\left[\mathrm{M}(\mathrm{CO})_{4}\{\mathrm{C}(\mathrm{OEt})\}_{2}-5,4-\right.$ $\left.\mathrm{C}_{6} \mathrm{H}_{2} \mathrm{~S}_{2}\right]$ with $\mathrm{M}=\mathrm{Cr}(\mathbf{1}, 24 \%$ yield $)$ and $\mathrm{M}=\mathrm{W}$ (5, 26\% yield), form through lithiation at only one $\alpha$-position (C5) of transTT- $\mathrm{Br}_{4}$ during the first lithiation step and reaction with a carbonyl ligand of the metal carbonyl precursor. Anion protection via the metal acylate also facilitates a second lithium-halogen exchange reaction on an adjacent $\beta$-position. During the second lithiation step, an anion forms at C4 ( $\beta$-position), converting the acylate into a 5,4-metallacyclic bisacylate. The neutral mononuclear chelated biscarbene complexes are generated after alkylation with excess $\left[\mathrm{Et}_{3} \mathrm{O}\right]\left[\mathrm{BF}_{4}\right]$. The second mononuclear chelated biscarbene complexes have an additional butyl group attached to the $\mathrm{C}^{\prime}$-positions and $\mathrm{H} / \mathrm{Br}$ on the C4'-positions, $\left[\mathrm{M}(\mathrm{CO})_{4}\{\mathrm{C}(\mathrm{OEt})\}_{2}-5,4-\mathrm{C}_{6} \mathrm{H}_{0 / 1} \mathrm{~S}_{2}-5^{\prime}-\mathrm{C}_{4} \mathrm{H}_{9}-4^{\prime}-\right.$ $\mathrm{Br} / \mathrm{H}]$ with $\mathrm{M}=\mathrm{Cr}(2,18 \%$ yield $)$ and $\mathrm{M}=\mathrm{W}(6,15 \%$ yield $)$. During the first dilithiation, lithium-halogen exchange on the C5'-position results in the formation of $\mathrm{BuBr}$, followed by electrophilic substitution of $\mathrm{BuBr}$ at the $\mathrm{C}^{\prime}$-position (lithiated site). The presence of a bromine atom at the $\mathrm{C}^{\prime}$-position is an indication of an incomplete second lithiation.

The targeted bischelated dimetal tetracarbene complexes, $\left[\left\{\mathrm{M}(\mathrm{CO})_{4}[\mathrm{C}(\mathrm{OEt})]_{2}\right\}_{2}-5,4,5^{\prime}, 4^{\prime}-\mathrm{C}_{6} \mathrm{~S}_{2}\right]$ with $\mathrm{M}=\mathrm{Cr}(3,28 \%$ yield $)$ and $\mathrm{M}=\mathrm{W}(\mathbf{8}, 15 \%$ yield $)$, formed as major products of the reaction. The low yield of $\mathbf{8}$ is a result of by-product formation, the second modified dimetal carbene complex $\left[\mathrm{W}(\mathrm{CO})_{4}\{\mathrm{C}\right.$ $\left.(\mathrm{OEt})\}_{2}-5,4-\mathrm{C}_{6} \mathrm{~S}_{2}-5^{\prime}-\mathrm{OEt}-4{ }^{\prime}-\mathrm{C}\left\{\mathrm{CH}_{2} \mathrm{CH}_{3}\right\}_{2} \mathrm{C}(\mathrm{OEt})\left\{\mathrm{W}(\mathrm{CO})_{5}\right\}\right]$ 7. The mechanism for the formation of 7 is not clear, but $\mathrm{C}_{\text {carb }}-\mathrm{C}_{\text {carb }}$ coupling, bond-breaking and formation reactions are required. However, it is clear that the acylate precursor intermediate for $\mathbf{7}$ is the same as that required for $\mathbf{8}$ and modifications could reasonably occur either before or after alkylation. The second dinuclear carbene complex, from the reaction with chromium hexacarbonyl, is the triscarbene complex $\left[\mathrm{Cr}(\mathrm{CO})_{4}\{\mathrm{C}(\mathrm{OEt})\}_{2}\right.$ $\left.5,4-\mathrm{C}_{6} \mathrm{HS}_{2}-5^{\prime}-\mathrm{C}(\mathrm{OEt}) \mathrm{Cr}(\mathrm{CO})_{5}\right]$ (4, 2\% yield). This product is an indication that the second lithiation step resulted in only one acylate to be converted into a 5,4-metallacyclic bisacylate, and the $\mathrm{C5}^{\prime}$-acylate is left intact.

trans-DTT-Br ${ }_{4}$ was used as starting material in the next two reactions (Scheme 1(c) and (d)). One mono- and two dimetal carbene complexes form during the reaction with chromium hexacarbonyl and with trans-DTT as spacer. The dimetal complexes are of two types, i.e. a biscarbene and a bischelated tetracarbene complex. Repeating the reaction with tungsten hexacarbonyl, results in two mono- and three dinuclear carbene complexes. The anticipated mononuclear chelated biscarbene complexes, $\left[\mathrm{M}(\mathrm{CO})_{4}\{\mathrm{C}(\mathrm{OEt})\}_{2}-5,4-\mathrm{C}_{8} \mathrm{H}_{2} \mathrm{~S}_{3}\right]$ with $\mathrm{M}=\mathrm{Cr}(\mathbf{9}, 3 \%$ yield) and $\mathrm{M}=\mathrm{W}(\mathbf{1 2}, 2 \%$ yield), formed in trace amounts. Dimetal tetracarbene complexes, $\left[\left\{\mathrm{M}(\mathrm{CO})_{4}[\mathrm{C}(\mathrm{OEt})]_{2}\right\}_{2}-5,4,5^{\prime}, 4^{\prime}-\right.$ $\left.\mathrm{C}_{8} \mathrm{~S}_{3}\right] \mathrm{M}=\mathrm{Cr}$ (11, 43\% yield) and $\mathrm{M}=\mathrm{W}$ (16, 51\% yield), formed as the targeted major products. The known chromium and tungsten biscarbene complexes of trans-DTT, with C5 and C5' pentacarbonyl carbene fragments (10 and 13 respectively), formed in trace amounts ( $<5 \%$ yield, Scheme $1(\mathrm{c})$ and (d)). ${ }^{35}$ Their formation is a result of dilithiation at the $\alpha$-positions, along with nucleophilic attack of the dianions on carbonyl carbon atoms of two metal hexacarbonyls, followed by quenching the resulting diacyl-dimetallates with $\left[\mathrm{Et}_{3} \mathrm{O}\right]\left[\mathrm{BF}_{4}\right]$. For the tungsten reaction (Scheme $1(\mathrm{~d})), \quad\left[\mathrm{W}(\mathrm{CO})_{4}\{\mathrm{C}(\mathrm{OEt})\}_{2}-5,4-\right.$ $\left.\mathrm{C}_{8} \mathrm{H}_{0 / 1} \mathrm{~S}_{3}-5^{\prime}-\mathrm{C}_{4} \mathrm{H}_{9}-4^{\prime}-\mathrm{Br} / \mathrm{H}\right] \quad$ (14) and $\left[\mathrm{W}(\mathrm{CO})_{4}\{\mathrm{C}(\mathrm{OEt})\}_{2}-5,4-\right.$ $\left.\mathrm{C}_{8} \mathrm{H}_{1} \mathrm{~S}_{3}-5^{\prime}-\mathrm{C}(\mathrm{OEt}) \mathrm{W}(\mathrm{CO})_{5}\right]$ (15) were additionally isolated in low yields. 
(a)<smiles>Brc1sc2c(Br)c(Br)sc2c1Br</smiles>

(i) $n$-BuLi, $-78^{\circ} \mathrm{C}$ (ii) $\mathrm{Cr}(\mathrm{CO})_{6}$ (iii) $n$-BuLi, $-78^{\circ} \mathrm{C}$ (iii) $\left[\mathrm{Et}_{3} \mathrm{O}\right]\left[\mathrm{BF}_{4}\right]$<smiles></smiles>
1, $24 \%$ EtO

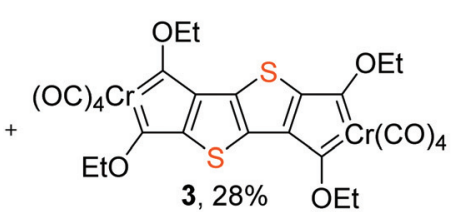

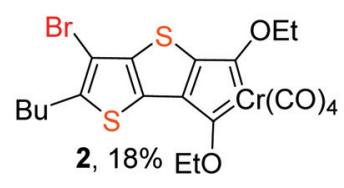

(b)

<smiles></smiles><smiles></smiles>

6. $15 \%$ OEt

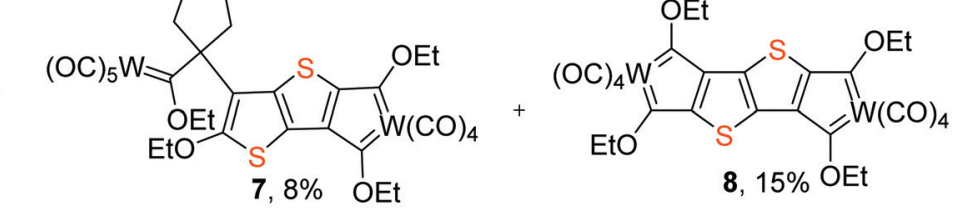

(c)

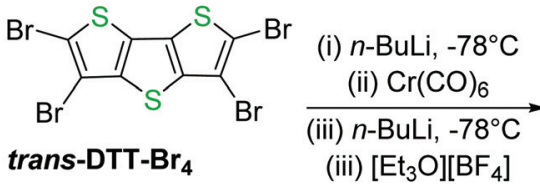<smiles></smiles>

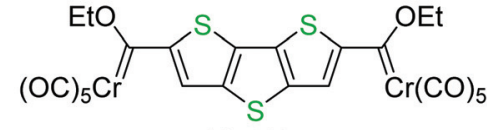

10. $2 \%$

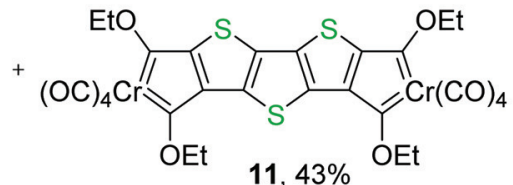

(i) $n$-BuLi, $-78^{\circ} \mathrm{C}$

(d)

trans-DTT-Br 4

(ii) $\mathrm{W}(\mathrm{CO})_{6}$ (iii) $n-\mathrm{BuLi},-78^{\circ} \mathrm{C}$

(iii) $\left[\mathrm{Et}_{3} \mathrm{O}\right]\left[\mathrm{BF}_{4}\right]$

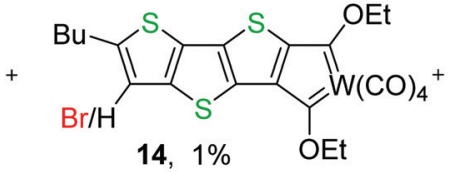<smiles>CCOC1=[N+]([O-])C(OCC)c2c1sc1c2=c2c=1sc1ccsc21</smiles><smiles>CCOC(c1cc2sc3cc(C(OCC)=[N+]([O-])O[Na])sc3c2o1)=[N+]([O-])[O-]</smiles>

13, $4 \%$



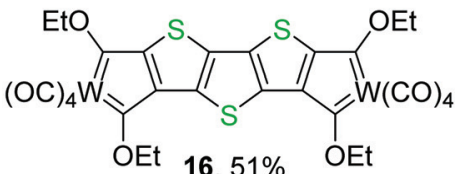

Scheme 1 Preparation of new chelated FCCs of group $6(\mathrm{Cr}, \mathrm{W})$ metal carbonyls from tetrabrominated (di)thienothiophene precursors with sulphur atoms in the up-down(-up) orientation.

The chelated carbene synthesis reactions, carried out with cis-DTT-Br ${ }_{4}$ as starting material (Scheme 2), did not proceed smoothly. The use of chromium hexacarbonyl as metal precursor yielded no stable, isolable products, while $\left[\left\{\mathrm{W}(\mathrm{CO})_{4}[\mathrm{C}\right.\right.$ $\left.\left.(\mathrm{OEt})]_{2}\right\}_{2}-5,4,5^{\prime}, 4^{\prime}-\mathrm{C}_{8} \mathrm{~S}_{3}\right](\mathbf{1 7}, 13 \%)$ is the only identifiable product from the reaction with tungsten hexacarbonyl. We ascribe the low yield of $13 \%$ to steric congestion at the termini of the bent thiophene band as a result of the curvature of the linker DTT.

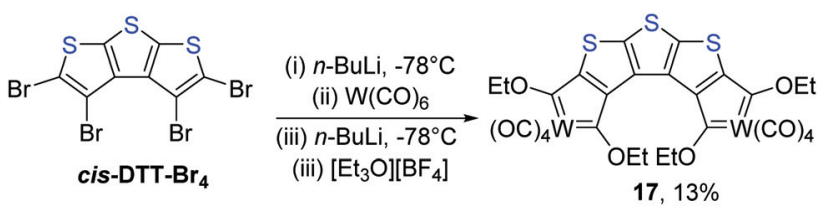

Scheme 2 Preparation of a new tungsten(0) chelated FCC from a tetrabrominated dithienothiophene precursor with sulphur atoms in the upup-up orientation. 


\section{Spectroscopic characterization}

NMR spectroscopy. NMR spectra were recorded in $\mathrm{CDCl}_{3}$ and the ${ }^{1} \mathrm{H}$ NMR data are summarized in Table 1.

The metallacycle in each of the complexes 1-17 display two carbene ligands in different electronic environments due to their orientations with respect to the sulphur in the adjacent thiophene ring.

Comparing the monochelated biscarbene complexes of trans-TT (1 (Cr) and $\mathbf{5}(\mathrm{W}))$ to their analogous cis-TT carbene complexes, the $\mathrm{H}^{\prime}{ }^{\prime}$ resonances are $c a .0 .15(\mathrm{Cr})$ and $0.22 \mathrm{ppm}$ (W) more downfield and the $\mathrm{H} 4^{\prime}$ resonances $c a$. $0.20(\mathrm{Cr})$ and 0.25 ppm (W) more upfield. ${ }^{32}$ This is a result of the larger extent of $\pi$-conjugation and more delocalised $\pi$-orbital electrons in trans-TT compared to cis-TT, allowing electron density to be withdrawn from the 5'-position throughout the trans-TT spacer in a carbene complex. ${ }^{36}$ The proton resonances are very similar when comparing the monochelated carbene complexes of trans-TT, (1 (Cr) and $5(\mathrm{~W}))$ to their analogous trans-DTT carbene complexes (9 $(\mathrm{Cr})$ and $\mathbf{1 2}(\mathrm{W}))$. In the case of $\mathbf{1}$ and $\mathbf{5}$, the $\mathrm{H}^{\prime}$ ' and $\mathrm{H} 4$ ' resonances are slightly more downfield and upfield (ca. $0.1 \mathrm{ppm}$ ), respectively (Table 1).

The effect of the number of annulated rings can be estimated by comparing the $\mathrm{H} 4$ and $\mathrm{H} 5$ resonances for the thiophene (T) and up-up(-up) thienylene precursors, cis-TT and cis-
DTT, with the monochelate biscarbene complex derivatives (Fig. 2). In the case of a single thienyl ring chelate carbene complex, T-[Cr], ${ }^{25}$ a significantly larger difference between H5

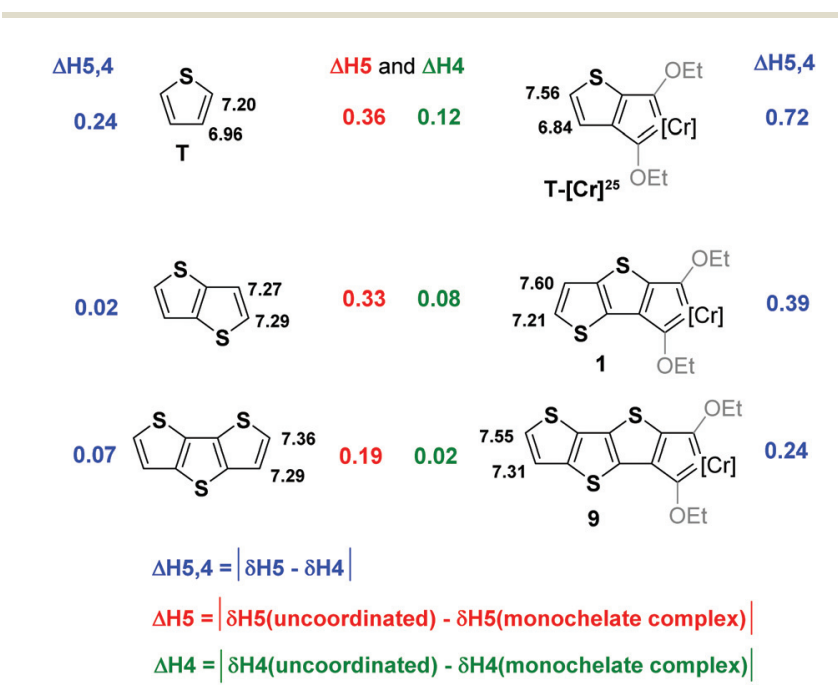

Fig. 2 H4 and H5 chemical shift (ppm) differences observed for thiophene building blocks and their corresponding monochelate biscarbene complexes of chromium; T-[Cr], ${ }^{25} 1$ and 9.

Table $1{ }^{1} \mathrm{H}$ NMR chemical shifts $(\delta)$ of the carbene complexes, recorded in $\mathrm{CDCl}_{3}$
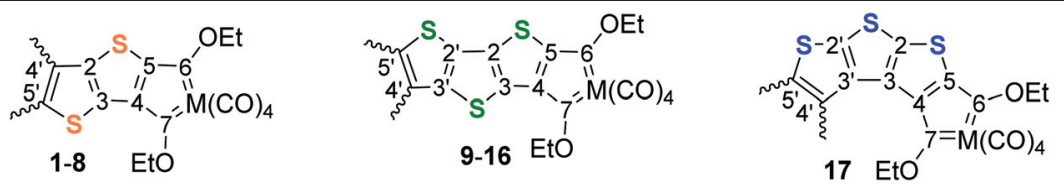

\begin{tabular}{|c|c|c|c|c|c|c|}
\hline Complex & $\mathrm{H} 4^{\prime}$ & $\mathrm{H}^{\prime}$ & $\mathrm{OEt}^{a}$ & OEt & $\mathrm{Bu}^{b}$ & $\mathrm{Et}_{2}{ }^{e}$ \\
\hline 1 & 7.21 & 7.60 & $4.78,1.70$ and $4.72,1.61$ & & & \\
\hline 2 & & & $4.74,1.68$ and $4.69,1.60$ & & $2.87,1.71,1.43,0.97$ & \\
\hline 3 & & & $4.71,1.67$ and $4.70,1.62$ & & & \\
\hline 4 & 8.91 & & $4.75,1.70$ and $4.72,1.62$ & $5.34^{c}, 1.86^{c}$ & & \\
\hline 5 & 7.20 & 7.71 & $4.54,1.71$ and $4.50,1.61$ & & & \\
\hline $6 \mathrm{H}$ & 7.56 & & $4.50,1.68$ and $4.48,1.62$ & & $2.82,1.71,1.44,0.97$ & \\
\hline $6 \mathrm{Br}$ & & & $4.51,1.69$ and $4.48,1.61$ & & $2.82,1.69,1.44,0.97$ & \\
\hline 7 & & & $4.54,1.69$ and $4.47,1.59$ & $5.06^{c}, 1.69^{c}, 4.12^{d}, 1.44^{d}$ & & $2.39,2.16,0.71,0.71$ \\
\hline 8 & & & $4.56,1.71$ and $4.48,1.60$ & & & \\
\hline 9 & 7.31 & 7.55 & $4.78,1.72$ and $4.71,1.61$ & & & \\
\hline 11 & & & $4.77,1.71$ and $4.70,1.61$ & & & \\
\hline 12 & 7.32 & 7.60 & $4.55,1.73$ and $4.50,1.61$ & & & \\
\hline $14 \mathrm{Br}$ & & & $4.55,1.74$ and $4.48,1.60$ & & $2.88,1.74,1.44,0.97$ & \\
\hline $14 \mathrm{H}$ & 7.48 & & $4.55,1.74$ and $4.49,1.61$ & & $2.88,1.75,1.44,0.97$ & \\
\hline 15 & 8.74 & & $4.51,1.74$ and $4.48,1.63$ & $5.17^{c}, 1.76^{c}$ & & \\
\hline 16 & & & $4.54,1.72$ and $4.47,1.62$ & & & \\
\hline 17 & & & $4.62,1.63$ and $4.50,1.53$ & & & \\
\hline
\end{tabular}

${ }^{a}$ Proton chemical shifts for the ethoxy fragments are reported with the first value being the chemical shift of the methylene group, and the second the chemical shift of the methyl group. The first set of methylene and methyl group resonances belongs to the ethoxy fragment coordinated through the $\mathrm{C} 7$ carbene, and the second set of values to the ethoxy fragment coordinated through the C6 carbene. ${ }^{b}$ Proton chemical shifts for the $\mathrm{CH}_{2} \mathrm{CH}_{2} \mathrm{CH}_{2} \mathrm{CH}_{3}$ fragment are reported with the first value being the chemical shift of the first methylene group adjacent to the C5' atom, followed by the second and third methylene group's values. The last chemical shift belongs to the methyl group. ${ }^{c}$ Proton chemical shifts for the ethoxy fragment, coordinated through the $\mathrm{C6}^{\prime}$ carbene, are reported with the first value being the chemical shift of the methylene group, and the second the chemical shift of the methyl group. ${ }^{d}$ Proton chemical shifts for the C5'-ethoxy fragment, reported with the first value being the chemical shift of the methylene group, and the second the chemical shift of the methyl group. ${ }^{e}$ Proton chemical shifts for the $\left(\mathrm{C}^{\prime} \mathrm{CEt} \mathrm{t}_{2}\right)$-ethyl fragments, reported with the first values being the chemical shifts of the methylene groups, and the second the chemical shift of the methyl groups. 
and $\mathrm{H} 4$ chemical shifts $(\Delta \mathrm{H} 5,4$ in Fig. 2$)$ in the complex compared to the precursor thiophene is indicative of polarisation in the thienyl ring. This we ascribe to the one thiophene double bond being involved in the delocalisation of electron density of the biscarbene chelate ring which has an adverse effect on electron delocalisation in the single thiophene ring. This is not the case for the furthest (uncoordinated) thiophene ring in trans-TT and trans-DTT biscarbene chelates. Hence, the polarisation in the thiophene ring decreases as the number of annulated thiophenes increase, so that $\Delta \mathrm{H} 5,4$ increase in the order $\mathbf{9}<\mathbf{1}<\mathbf{T}$-[Cr]. Moreover, the difference between the precursor absolute value for both $\mathrm{H} 5$ and $\mathrm{H} 4$, and the chelate complex derivative $\mathrm{H} 5$ and $\mathrm{H} 4$ values, also decreases as the number of annulated rings in the complex increases, so that $\Delta \mathrm{H} 4$ and $\Delta \mathrm{H} 5$ also increase in the order $\mathbf{9}<\mathbf{1}<\mathbf{T}-[\mathbf{C r}]$ (Fig. 2). Both trends support a lesser degree of electron delocalisation (and ring polarisation increase) in the order DTT $>\mathrm{TT}>\mathrm{T}$ as the annulated ring number decreases.

${ }^{13} \mathrm{C}$ NMR data are summarized in Table 2 . The carbene carbon chemical shifts of the metallacyclic biscarbene component, C7 and C6, are mostly unaffected by the type of annulated thienylene spacer present in the molecule, but affected by the position of attachment and the nature of the transition metal.
Considering the triscarbene complex of trans-TT (4), the C6 and C6' $^{\prime}$ carbene carbon chemical shifts are more downfield compared to the analogous cis-TT carbene complex. ${ }^{32}$ Comparing the metallacyclic tetracarbonyl biscarbene fragment of 4 to its intramolecular C5' pentacarbonyl carbene fragment, the carbene signals are upfield and the carbonyl carbon signals downfield.

The C7 carbene carbon resonance is more upfield in the chromium bischelated carbene complex of trans-TT (3), compared to the analogous cis-TT carbene complex. ${ }^{32}$ The same effect is seen in comparing 16 (trans-DTT) with 17 (cis-DTT). The larger extent of $\pi$-conjugation in trans-TT and trans-DTT, compared to their constitutional isomers, permits more electron density to be delocalised to the $\mathrm{C} 7$ carbene carbons of 3 and 16. In addition, the linear structure of $\mathbf{1 6}$ compared to the bent molecular structure of 17 results in better $\mathrm{p}_{\pi}$-orbital overlap in the conjugated pathway of $\mathbf{1 6}$ (Fig. 3). As a result, greater shielding of the carbene carbon atoms in $\mathbf{1 6}$ is found, compared to those in 17. Steric congestion in $\mathbf{1 7}$ results in the chemical non-equivalence of the two cis carbonyl ligands (disruption of the symmetry) and two separate resonances, at 212.4 and $210.7 \mathrm{ppm}$, are observed instead of the expected one. The same duplication is observed in the methyl resonances of C7OEt and C6OEt. Chemical shift assignments of

Table $2{ }^{13} \mathrm{C}$ NMR chemical shifts $(\delta)$ of the carbene complexes, recorded in $\mathrm{CDCl}_{3}$
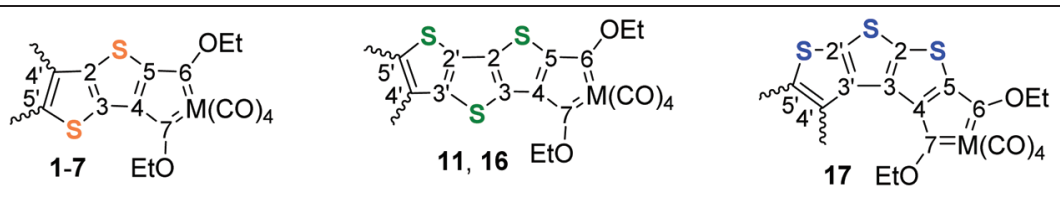

\begin{tabular}{|c|c|c|c|c|c|c|c|c|}
\hline Complex & $\mathrm{C} 4$ & C5 & $\mathrm{C} 4^{\prime}$ & $\mathrm{C}^{\prime}$ & $\mathrm{C}_{\text {carb }}{ }^{a}$ & $\mathrm{C}_{\mathrm{co}}^{b}$ & $\mathrm{OEt}^{c}$ & $\mathrm{Bu} / \mathrm{Et}$ \\
\hline 1 & 157.0 & 163.4 & 120.0 & 132.8 & $314.4,309.2$ & 243.0 and $242.9,227.8$ & n.o., $15.1 ; 76.4,15.1$ & \\
\hline 2 & 157.2 & 160.8 & 101.9 & 148.3 & $315.0,308.2$ & 243.2 and $242.8,227.8$ & n.o., $15.0 ; 76.4,15.0$ & $\begin{array}{l}30.3^{d}, 32.5^{d}, 22.1^{d}, \\
13.7^{d}\end{array}$ \\
\hline 3 & 157.8 & 165.0 & & & $314.6,310.0$ & 244.8 and $242.4,227.5$ & n.o., 15.1; n.o., 15.1 & \\
\hline 4 & $e$ & & $e$ & $e$ & $\begin{array}{l}314.6,310.9, \\
321.7^{f}\end{array}$ & $\begin{array}{l}243.3 \text { and } 243.0,227.8, \\
222.9^{f}, 216.8^{f}\end{array}$ & n.o., $15.1 ;$ n.o., $15.0 ;$ n.o. $^{f}, 15.8^{f}$ & \\
\hline 5 & 161.3 & 169.6 & 120.4 & 133.0 & $286.8,282.7$ & 220.5 and $220.2,212.5$ & $79.7,14.8 ; 79.5,14.7$ & \\
\hline 7 & 161.9 & 163.6 & 147.1 & 165.4 & $\begin{array}{l}287.5,278.8, \\
341.9^{f}\end{array}$ & $\begin{array}{l}221.7 \text { and } 219.2,212.4 \text {, } \\
200.9^{f}, 197.2^{f}\end{array}$ & $\begin{array}{l}79.7,14.8 ; 79.1,14.8 ; 81.5^{f}, \\
14.7^{f} ; 70.1^{g}, 14.7^{g}\end{array}$ & $70.7^{h}, 26.8^{h}, 9.1^{h}$ \\
\hline 11 & 157.6 & 162.4 & & & $314.4,308.0$ & 243.9 and $242.7,227.6$ & $76.7,15.0 ;$ n.o., 15.0 & \\
\hline 16 & 162.1 & 169.0 & & & $286.0,280.7$ & 220.4 and $219.7,212.0$ & $79.7,14.7 ; 79.6,14.7$ & \\
\hline 17 & 162.1 & 169.0 & & & $296.5,282.9$ & $\begin{array}{l}219.4 \text { and } 216.8,212.4 \text { and } \\
210.7^{i}\end{array}$ & $\begin{array}{l}80.3,14.8 \text { and } 14.7 ; 79.5,14.9 \\
\text { and } 14.9\end{array}$ & \\
\hline
\end{tabular}

\footnotetext{
${ }^{a}$ Carbene carbon chemical shift of C7 is reported first, followed by C6. ${ }^{b}$ Carbon chemical shifts for the metal carbonyls are reported with the first two values being the chemical shifts of the carbonyls trans to the carbene carbons, and the third the chemical shift of the carbonyls cis to the carbene carbons. ${ }^{c}$ Carbon chemical shifts for the ethoxy fragment are reported with the first value being the chemical shift of the methylene group, and the second the chemical shift of the methyl group, respective for the $\mathrm{C} 7$ (first set of values) and C6 (second set of values) carbene fragments. ${ }^{d}$ Carbon chemical shifts for the $\mathrm{CH}_{2} \mathrm{CH}_{2} \mathrm{CH}_{2} \mathrm{CH}_{3}$ fragment are reported with the first value being the chemical shift of the first methylene group after the $\mathrm{C} 5^{\prime}$ atom, followed by the second and third methylene group's values. The last chemical shift belongs to the methyl group. ${ }^{e}$ Assignments could not be made unambiguously. ${ }^{f}$ Carbon chemical shifts for the ${ }^{6}$ '-carbene fragment. The carbon chemical shifts for the pentacarbonyls are reported with the first value being the chemical shift of the carbonyl trans to the carbene carbon, and the second the chemical shift of the carbonyls cis to the carbene carbon. Ethoxy fragment resonances are reported with the first value being the chemical shift of the methylene group, and the second the chemical shift of the methyl group. ${ }^{g}$ Carbon chemical shifts for the C5'-ethoxy fragment, reported with the first value being the chemical shift of the methylene group, and the second the chemical shift of the methyl group. ${ }^{h}$ Carbon chemical shifts for the $\left(\mathrm{C} 4^{\prime} \mathrm{CEt}_{2}\right)$-fragment. The first value is the chemical shift of the $\mathrm{C}^{\prime} \mathrm{CEt}_{2}$ carbon, the second value the methylene and the third the methyl chemical shift. ${ }^{i}$ Two carbon chemical shifts are observed for the cis metal carbonyl ligands.
} 
(a)

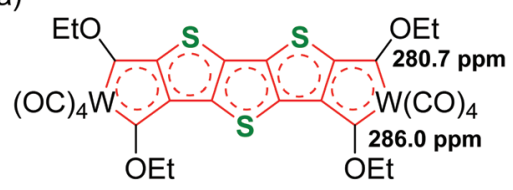

(b)

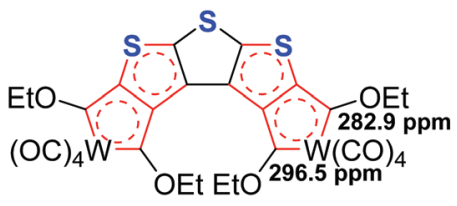

Fig. 3 Molecular structures of linear 16 (a) and bent 17 (b), two isomers of the DTT bischelated tetracarbene complexes, with ${ }^{13} \mathrm{C}$ NMR indicated for the carbene carbon atoms.

C2 and C3 could not be made unambiguously for the compounds.

Infrared spectroscopy. The infrared data for 1-3, 5, 7, 11 and 16 are summarized in the ESI, Table S6. $\dagger$ These compounds display the typical vibrational carbonyl stretching frequency "fingerprint" of a cis- $\mathrm{M}(\mathrm{CO})_{4} \mathrm{~L}_{2}$ system with $C_{\mathrm{s}}$ symmetry. ${ }^{37}$ In the case of 7 the molecule contains an additional metal pentacarbonyl carbene fragment $\left(\mathrm{M}(\mathrm{CO})_{5} \mathrm{~L}\right.$ system) with $C_{4 \mathrm{v}}$ square pyramidal symmetry. ${ }^{37}$ The $\mathrm{A}_{1}{ }^{(2)}$ vibrational band of the metal tetracarbonyl fragment of 7 overlap with the $\mathrm{E}$ and $\mathrm{A}_{1}{ }^{(2)}$ bands of the metal pentacarbonyl fragment, to give one strong broad band. Two bands are observed for the $\mathrm{B}_{1}$ mode of the metal pentacarbonyl fragment (the asymmetric vibration of the four carbonyl ligands in the same plane), when the IR spectrum is recorded in solvent hexane. However when the spectrum is recorded in DCM, only the expected one band is seen for the $\mathrm{B}_{1}$ mode.

\section{Single crystal X-ray molecular structures}

Single crystals suitable for X-ray diffraction were obtained from saturated solutions of either DCM $(\mathbf{1}-\mathbf{3}, \mathbf{5})$ or benzene $(\mathbf{1 1}, \mathbf{1 6})$, each layered with hexane. X-ray diffraction studies confirmed their molecular structures (Fig. 4) and selected bond lengths, angles and torsion angles are given in Table 3. The atom numbers employed are similar to the NMR assignments. A single crystal of 7 could be isolated, but the diffraction data set is of low resolution and therefore not included. However, the atom connectivity in the molecule can be deduced from the structure (see section S5, ESI $\dagger$ ).

Crystal structures of the octahedral chelated ethoxycarbene complexes have similar structural features. The octahedral metal tetracarbonyl fragment is attached to the spacer through two ethoxycarbene carbons (C7 and C6). The ethyl groups (C7 and $\mathrm{C} 6$ ) and metal moiety are on the same side of the $\left((\mathrm{CO})_{4} \mathrm{M}\right) \mathrm{C}_{\text {carb }}-\mathrm{O}(\mathrm{Et})$ bond $\left(\mathrm{C}_{\mathrm{carb}}-\mathrm{O} 7(\mathrm{Et})\right.$ and $\mathrm{C6}_{\text {carb }}-\mathrm{O} 6(\mathrm{Et})$ respectively), ensuing the favoured anti-isomer orientation. $^{38-41}$

To determine if the thienylene spacer and metallacyclic biscarbene component (carbene carbon atoms, metal and ethoxy fragments) are in the same plane, a mean plane is drawn
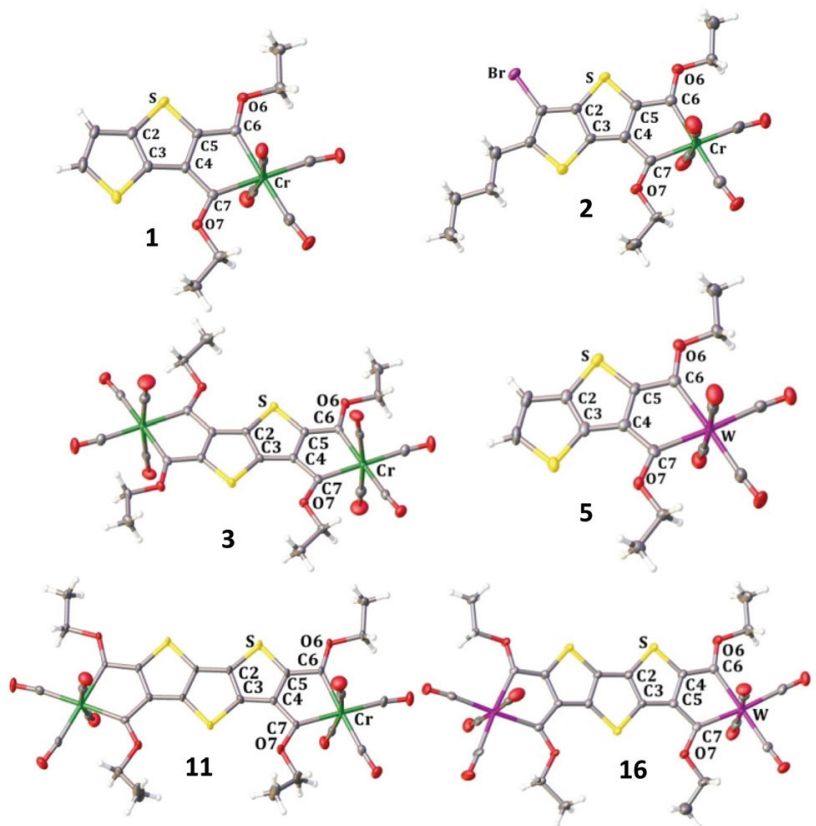

Fig. 4 The molecular structures of 1-3, 5, 11 and 16 with the atomic displacement ellipsoids shown at the $50 \%$ probability level.

through $\mathrm{C} 2, \mathrm{C} 3, \mathrm{C} 4$ and $\mathrm{C} 5$, and a second through $\mathrm{M}, \mathrm{C} 7_{\text {carb }}$, O7, $\mathrm{C6}_{\text {carb }}$ and O6. All of the crystal structures exhibited a near planar arrangement, as indicated by the angle measured between the two planes (Table 3). The larger tungsten metal in 5 and $\mathbf{1 6}$ accounts for the largest deviation from planarity of the molecules and the angle between the two mean planes is determined as 6.11 and $9.65^{\circ}$ (on one side of the molecule), respectively. All the structures in Fig. 4, except for the slightly curved monochelated complexes 1,2 and 5, adopt a linear arrangement, as a result of their annulated thiophene rings with sulphur atoms arranged in the up-down(-up) positions along with the presence of condensed chelates biscarbene fragments. This is not the case in the bent structures of annulated thiophenes with the sulphur atoms on the same side (compare also Fig. 3). ${ }^{32}$ The metal centers have an octahedral arrangement of ligands with small deviations in the bond angles caused by the chelate ring/s. The two cis carbonyl ligands axially arranged (and trans to each other) are slightly bent towards the inside of the chelated rings. The $(\mathrm{O}) \mathrm{C}_{c i s, \text { axial }^{-}}$ $\mathrm{M}-\mathrm{C}_{c i s, \text { axial }}(\mathrm{O})$ bond angles are measured to indicate the degree of deviation from linearity (Table 3 ). Another bond angle that is affected is the bite angle $\left(\mathrm{C}_{\mathrm{carb}}-\mathrm{M}-\mathrm{C} 7_{\mathrm{carb}}\right)$ of coordination for the chelate ring, and they are smaller than $90^{\circ}$. The $\mathrm{M}-$ $\mathrm{C}_{\text {carb }}$ bond lengths (with $\mathrm{C}_{\text {carb }}$ as $\mathrm{C}_{\text {carb }}$ or $\mathrm{C}_{\text {carb }}$ ) are all comparable within experimental error for the chromium and tungsten carbene complexes, respectively, with the $\mathrm{M}-\mathrm{C} \mathbf{6}_{\text {carb }}$ bond lengths mostly significantly longer compared to $\mathrm{M}-\mathrm{C} 7_{\text {carb }}$. The $\mathrm{C}_{\text {carb }}$-OEt averaged bond lengths ( $\mathrm{C}_{\text {carb }}-\mathrm{OEt}(\mathrm{Cr}: 1.320(7)$; W: $1.330(6)$ ) and $\mathrm{C}_{\text {carb }}-\mathrm{OEt}(\mathrm{Cr}: 1.320(5) ; \mathrm{W}: 1.318(6))$ are independent of the type of metal or annulated thienylene present in the molecule (Table 3). The same principle accounts for the 
Table 3 Selected bond lengths ( $(\AA)$ and angles $\left(^{\circ}\right)$ of $1-3,5,11$ and 16

\begin{tabular}{|c|c|c|c|c|c|c|}
\hline Complex & 1 & 2 & $3^{c}$ & 5 & $11^{c}$ & $16^{c}$ \\
\hline \multicolumn{7}{|l|}{ Bond lengths } \\
\hline $\mathrm{M}-\mathrm{C} 7_{\text {carb }}$ & $2.029(1)$ & $2.029(5)$ & $2.030(2)$ & $2.155(3)$ & $2.020(5), 2.025(5)$ & $2.161(6), 2.166(5)$ \\
\hline $\mathrm{M}-\mathrm{C} 6_{\mathrm{carb}}$ & $2.040(2)$ & $2.053(5)$ & $2.037(2)$ & $2.169(4)$ & $2.041(6), 2.029(4)$ & $2.175(4), 2.161(6)$ \\
\hline $\mathrm{C} 7_{\mathrm{carb}}-\mathrm{OEt}$ & $1.322(2)$ & $1.318(6)$ & $1.325(2)$ & $1.340(4)$ & $1.308(7), 1.325(7)$ & $1.326(7), 1.323(5)$ \\
\hline $\mathrm{C}_{\mathrm{carb}}-\mathrm{OEt}$ & $1.324(2)$ & $1.326(6)$ & $1.324(3)$ & $1.321(4)$ & $1.311(6), 1.323(6)$ & $1.316(6), 1.316(5)$ \\
\hline $\mathrm{M}-\mathrm{CO}_{\text {trans }}$ to $\mathrm{CO}{ }^{a}$ & $1.918(2)$ & $1.918(5)$ & $1.922(2)$ & $2.061(4)$ & $1.918(6), 1.913(6)$ & $2.053(5), 2.060(5)$ \\
\hline $\mathrm{M}-\mathrm{CO}_{\text {trans }}$ to carb ${ }^{a}$ & $1.878(2)$ & $1.884(6)$ & $1.890(2)$ & $2.021(4)$ & $1.897(6), 1.887(6)$ & $2.021(5), 2.021(6)$ \\
\hline $\mathrm{C} 7_{\mathrm{carb}}-\mathrm{C} 4$ & $1.443(3)$ & $1.451(7)$ & $1.450(3)$ & $1.438(6)$ & $1.454(8), 1.456(7)$ & $1.461(6), 1.463(8)$ \\
\hline $\mathrm{C} 6_{\mathrm{carb}}-\mathrm{C} 5$ & $1.438(2)$ & $1.444(7)$ & $1.441(3)$ & $1.447(5)$ & $1.449(7), 1.443(7)$ & $1.449(8), 1.449(7)$ \\
\hline $\mathrm{C} 2-\mathrm{C} 3$ & $1.383(3)$ & $1.379(7)$ & $1.386(3)$ & $1.378(6)$ & $1.390(8), 1.394(8)$ & $1.401(6), 1.390(8)$ \\
\hline C3-C4 & $1.420(2)$ & $1.418(7)$ & $1.418(3)$ & $1.425(5)$ & $1.418(7), 1.416(7)$ & $1.411(7), 1.420(7)$ \\
\hline C4-C5 & $1.384(2)$ & $1.377(6)$ & $1.382(3)$ & $1.388(5)$ & $1.385(8), 1.396(8)$ & $1.391(8), 1.392(6)$ \\
\hline $\mathrm{S}-\mathrm{C} 2$ & $1.736(2)$ & $1.732(5)$ & $1.732(2)$ & $1.739(3)$ & $1.722(6), 1.738(6)$ & $1.728(6), 1.732(4)$ \\
\hline S-C5 & $1.732(2)$ & $1.742(5)$ & $1.739(2)$ & $1.730(4)$ & $1.737(6), 1.724(5)$ & $1.732(4), 1.730(6)$ \\
\hline \multicolumn{7}{|l|}{ Bond angles } \\
\hline$(\mathrm{O}) \mathrm{C}_{c i s, \text { axial }}-\mathrm{M}-\mathrm{C}_{c i s, \text { axial }}(\mathrm{O})$ & $10.48(8)$ & $10.0(2)$ & $8.18(9)$ & $3.8(2)$ & $13.2(2), 13.3(2)$ & $3.1(2), 5.1(2)$ \\
\hline $\mathrm{C} 6_{\mathrm{carb}}-\mathrm{M}-\mathrm{C} 7_{\mathrm{carb}}$ & $81.67(6)$ & $81.7(2)$ & $81.80(8)$ & $77.3(1)$ & $82.5(2), 82.3(2)$ & $77.7(2), 77.7(2)$ \\
\hline $\mathrm{M}-\mathrm{C} 7_{\mathrm{carb}}-\mathrm{O} 7$ & $137.7(1)$ & $137.6(3)$ & $138.8(1)$ & $137.2(2)$ & $137.8(4), 138.4(4)$ & $137.1(3), 136.5(3)$ \\
\hline $\mathrm{M}-\mathrm{C6}_{\mathrm{carb}}-\mathrm{O} 6$ & $137.6(1)$ & $137.3(3)$ & $137.8(1)$ & $136.8(3)$ & $139.6(4), 137.7(3)$ & $137.6(3), 137.6(3)$ \\
\hline $\mathrm{M}-\mathrm{C} 7_{\mathrm{carb}}-\mathrm{C} 4$ & $113.4(1)$ & $113.4(3)$ & 113.1(1) & $114.9(2)$ & $113.7(3), 113.4(3)$ & $114.9(3), 114.5(3)$ \\
\hline $\mathrm{M}-\mathrm{C}_{\mathrm{carb}}-\mathrm{C} 5$ & $112.3(1)$ & $111.8(3)$ & $112.3(1)$ & $113.3(2)$ & $110.8(4), 112.2(3)$ & $113.1(3), 112.9(3)$ \\
\hline $\mathrm{O} 7-\mathrm{C} 7_{\mathrm{carb}}-\mathrm{C} 4$ & $108.8(1)$ & $109.0(4)$ & $108.1(2)$ & $107.9(3)$ & $108.3(4), 108.1(4)$ & $107.9(4), 109.0(4)$ \\
\hline $\mathrm{O} 6-\mathrm{C} 6{ }_{\mathrm{carb}}-\mathrm{C} 5$ & $110.1(1)$ & $110.9(4)$ & $109.7(2)$ & $109.9(3)$ & $109.5(4), 109.9(4)$ & $109.3(4), 109.4(4)$ \\
\hline \multicolumn{7}{|l|}{ Torsion angles } \\
\hline $\mathrm{M}-\mathrm{C} 7_{\mathrm{carb}}-\mathrm{C} 4-\mathrm{C} 5$ & $2.2(2)$ & $-5.4(5)$ & $1.6(2)$ & $-4.6(4)$ & $-3.2(6), 2.4(6)$ & $0.9(5), 8.8(5)$ \\
\hline $\mathrm{M}-\mathrm{C} 6_{\mathrm{carb}}-\mathrm{C} 5-\mathrm{C} 4$ & $-0.6(2)$ & $-1.3(5)$ & $-3.9(2)$ & $2.5(4)$ & $2.0(6), 0.2(6)$ & $-0.9(6),-3.6(6)$ \\
\hline $\mathrm{O} 7-\mathrm{C} 7_{\mathrm{carb}}-\mathrm{C} 4-\mathrm{C} 5$ & $-180.0(1)$ & $175.1(4)$ & $-179.3(2)$ & $178.0(3)$ & $-179.0(5),-173.8(4)$ & $-179.9(4),-169.8(4)$ \\
\hline $\mathrm{O} 6-\mathrm{C6}_{\mathrm{carb}}-\mathrm{C} 5-\mathrm{C} 4$ & $179.3(1)$ & $178.5(4)$ & $179.4(2)$ & $-178.1(3)$ & $-179.7(5),-176.0(4)$ & $-178.9(4), 179.2(4)$ \\
\hline Angle between two mean planes ${ }^{b}$ & 3.28 & 4.66 & 3.71 & 6.11 & $3.83,4.42$ & $0.61,9.65$ \\
\hline
\end{tabular}

${ }^{a}$ Average bond length. ${ }^{b}$ First mean plane drawn through C2, C3, C4 and C5, and the second through $\mathrm{M}, \mathrm{C} 7$ carb $, \mathrm{O} 7, \mathrm{C} 6$ carb ${ }^{\text {and }}$ O6. ${ }^{c}$ First set reported for M1 and the second for M2. In the case of $\mathbf{3}$ only one set of values is reported, as the values are identical due to the symmetry of the molecule.

bond lengths of the bonds connecting the carbene carbons to the annulated thienylene $\left(\mathrm{C}_{\mathrm{carb}}-\mathrm{C} 4\right.$ and $\left.\mathrm{C6}_{\mathrm{carb}}-\mathrm{C} 5\right)$.

Ethoxycarbene complexes have characteristic carbene carbon angles of $130^{\circ}\left(\mathrm{M}-\mathrm{C}_{\mathrm{carb}}-\mathrm{O}\right), 125\left(\mathrm{M}-\mathrm{C}_{\mathrm{carb}}-\mathrm{C} 5\right)$ and $105^{\circ}$ $\left(\mathrm{O}-\mathrm{C}_{\mathrm{carb}}-\mathrm{C} 5\right) \cdot{ }^{38-41}$ In the case of chelated ethoxycarbene complexes the $\mathrm{M}-\mathrm{C}_{\mathrm{carb}}-\mathrm{O}$ bond angle is increased to an average magnitude of $137.8(3)^{\circ}$, the $\mathrm{M}-\mathrm{C} 7_{\mathrm{carb}} / \mathrm{C}_{\mathrm{carb}}-\mathrm{C} 5 / \mathrm{C} 4$ bond angle significantly decreased to $113.2^{\circ}(3)$ and the $\mathrm{O}-\mathrm{C}_{\text {carb }}-\mathrm{C} 5 / \mathrm{C} 4$ bond angle increased to $109.1(4)^{\circ}$ because of the metallacycle ring strain effect on coordination (Table 3).

\section{Cyclic voltammetry and molecular orbital calculations}

Cyclic voltammetry (CV) and linear sweep (LSV) experiments were performed for 1, 3, 11, 16, 18-21 (Fig. 5). The choice of compounds for electrochemical studies was justified by the aim to investigate the effect of the following on the redox processes; monocarbene vs. mononuclear chelated biscarbene (e.g. 18 vs. 1), mononuclear chelated carbene vs. dinuclear chelated carbene complexes (e.g. 1 vs. 3), Cr vs. W (11 vs. 16) and different thienylene spacers (condensed thiophenes with the sulphur atoms in the up-up (19) vs. up-down (3) vs. up-up-up (20) vs. up-down-up (e.g. 21) positions). The electrochemical data are summarized in Table 4 and Table S7, ESI $\uparrow$ and the CVs for the reduction processes are displayed in Fig. 6. Ferrocene $(\mathrm{FcH})$ was used as internal standard for 16, 18, 20<smiles></smiles><smiles></smiles><smiles></smiles><smiles></smiles>

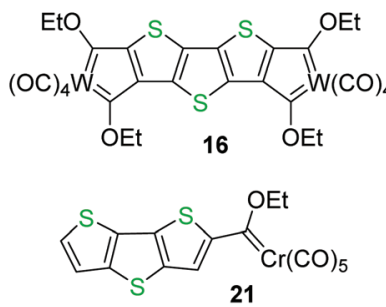

Fig. 5 Compounds selected for electrochemical studies.

and 21, and decamethylferrocene $\left(\left[\mathrm{Fe}\left(\eta^{5}-\mathrm{C}_{5} \mathrm{Me}_{5}\right)_{2}\right]\right)$ was used for the remainder of the compounds (to avoid overlap observed with $\mathrm{FCH})$. The $\left[\mathrm{Fe}\left(\eta^{5}-\mathrm{C}_{5} \mathrm{Me}_{5}\right)_{2}\right]^{0 /+1}$ couple was referenced to the $\mathrm{FcH}^{0 /+1}$ couple $\left(E^{\circ \prime}=0.00 \mathrm{~V}\right)$, to enable comparison with the results of the compounds measured with $\mathrm{FcH}$ as internal standard. 


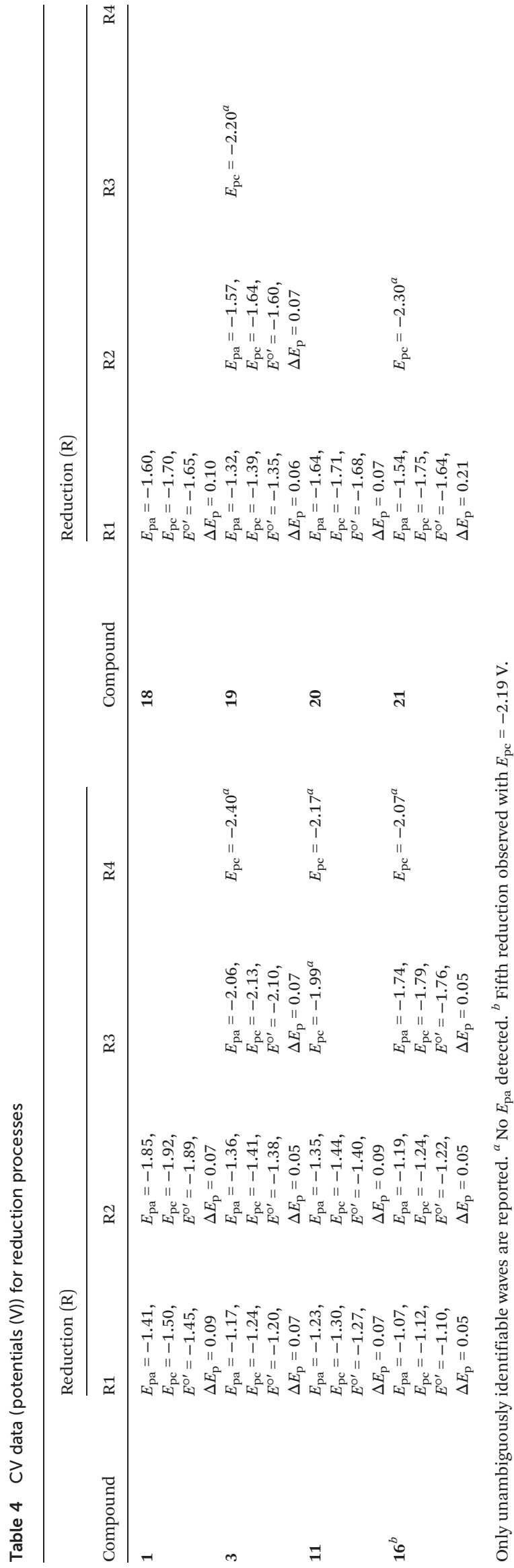

The CV data for the oxidation processes (O) are summarized in Table S7 (ESI $\dagger$ ). The observed oxidation processes are metalbased $^{21,36}$ and predominantly chemically and electrochemically irreversible, hence limited information could be extracted from the results. The resulting oxidations processes cannot be assigned unambiguously as $\mathrm{Cr}^{0 / \mathrm{I}}$ up to $\mathrm{Cr}^{\mathrm{V} / \mathrm{VI}}$ couples are possible, as well as the oxidation of electrochemically produced reactive $\mathrm{Cr}^{\mathrm{O} / \mathrm{I}}$ and $\mathrm{Cr}^{\mathrm{I} / \mathrm{II}}$ intermediates. The large irreversible oxidation processes observed, range from two to six electron processes and are discussed in the ESI section S7. $\dagger$

The reduction processes $(\mathrm{R})$ are centred on the carbene double bond $(\mathrm{M}=\mathrm{C})$, to yield the radical anion; $\mathrm{M}-\mathrm{C}^{\bullet-21,36}$ The carbene double bond reduction is reversible for tungsten carbene complexes on $\mathrm{CV}$ time scale. For chromium carbene complexes, this reduction varies between reversible/quasi-/irreversible reductions ${ }^{42}$ due to the fast decomposition rate of the radical anion product. ${ }^{43}$ In the case of $\mathbf{1 8}$ the reduction is irreversible as $\Delta E_{\mathrm{p}}$ is $100 \mathrm{mV}$ (Table 4 ) and the $i_{\mathrm{pc}} / i_{\mathrm{pa}}$ current ratio is far from unity. The high reactivity/subsequent decomposition that is associated with the $\mathrm{Cr}-\mathrm{C}^{\cdot-}$ species, results in the low current ratio observed. ${ }^{42}$ In aprotic solvents, the radical anion that is generated is extensively unstable and subsequent reactions destroy this electrochemically generated species quickly. The $\mathrm{Cr}=\mathrm{C}$ double bond reduction of $\mathbf{1 8}$ represents a one-electron reduction as the $i_{\mathrm{pc}}$ value of $\mathrm{R} 1$ match the $i_{\mathrm{pa}}$ value of $\mathrm{FcH}$ (known to signify a one-electron redox process, Fig. 6(a)).

During a one-electron transfer process, alkene reduction occurs at far negative potentials and conjugated alkenes at slightly larger potentials. ${ }^{42}$ Redox potentials are considered a good measure of the tendency of a system to undergo reduction (acquire electrons). ${ }^{21}$ The first reduction (R1) potentials of the monocarbene complexes 18, 20 and 21 are around $-1.66 \mathrm{~V}$ vs. $\mathrm{FcH}^{\mathrm{0} /+1}$, which is far more negative compared to the remaining chelated carbene complexes (Table 4, R1). Comparing R1 of $\mathbf{1 8}$ to R1 of the chromium thiophene monocarbene complex $(-1.76 \mathrm{~V})$, the latter is found at an even greater negative potential. ${ }^{42}$

Two separate reductions are observed in the $\mathrm{CV}$ of $\mathbf{1}$ (Fig. 6(a)). R1 can be ascribed as a quasi-reversible reduction of $\mathrm{Cr}=\mathrm{C}$ as $\Delta E_{\mathrm{p}}=90 \mathrm{mV}$ and $i_{\mathrm{pc}} / i_{\mathrm{pa}}=2$. R1 is at $-1.45 \mathrm{~V}$, which is less negative compared to the R1 value of 18. R2 represents an irreversible reduction of $\mathrm{Cr}=\mathrm{C}$ as the current ratio $i_{\mathrm{pc}} / i_{\mathrm{pa}}$ is ca. 4. $\mathrm{R} 1$ and $\mathrm{R} 2$ represent a one-electron reduction as their $i_{\mathrm{pc}}$ values match the $i_{\mathrm{pa}}$ value of the $\left[\mathrm{Fe}\left(\eta^{5}-\mathrm{C}_{5} \mathrm{Me}_{5}\right)_{2}\right]^{0 /+1}$ couple (one-electron redox process, Fig. 6(a)). Comparing the chelated biscarbene complex to a standard thiophene biscarbene complex, $\mathrm{R} 1$ of the latter is at $-1.85 \mathrm{~V}(0.4 \mathrm{~V}$ more negative). ${ }^{42}$ This is in sharp contrast to the results found for chelated monocarbene complexes, where they are reduced at more negative potentials compared to non-chelated carbene complexes in the same study. ${ }^{21}$ Four one-electron reductions are observed in the CV of 3 (Fig. 6(b)). R1 and R2 are overlapping, but still distinguishable and are considered quasi-reversible reductions as their $i_{\mathrm{pc}} i_{\mathrm{pa}}$ current ratios are around 2. R3 and $\mathrm{R} 4$ are irreversible reductions with the current ratio of $\mathrm{R} 3 \mathrm{ca} .4$ 

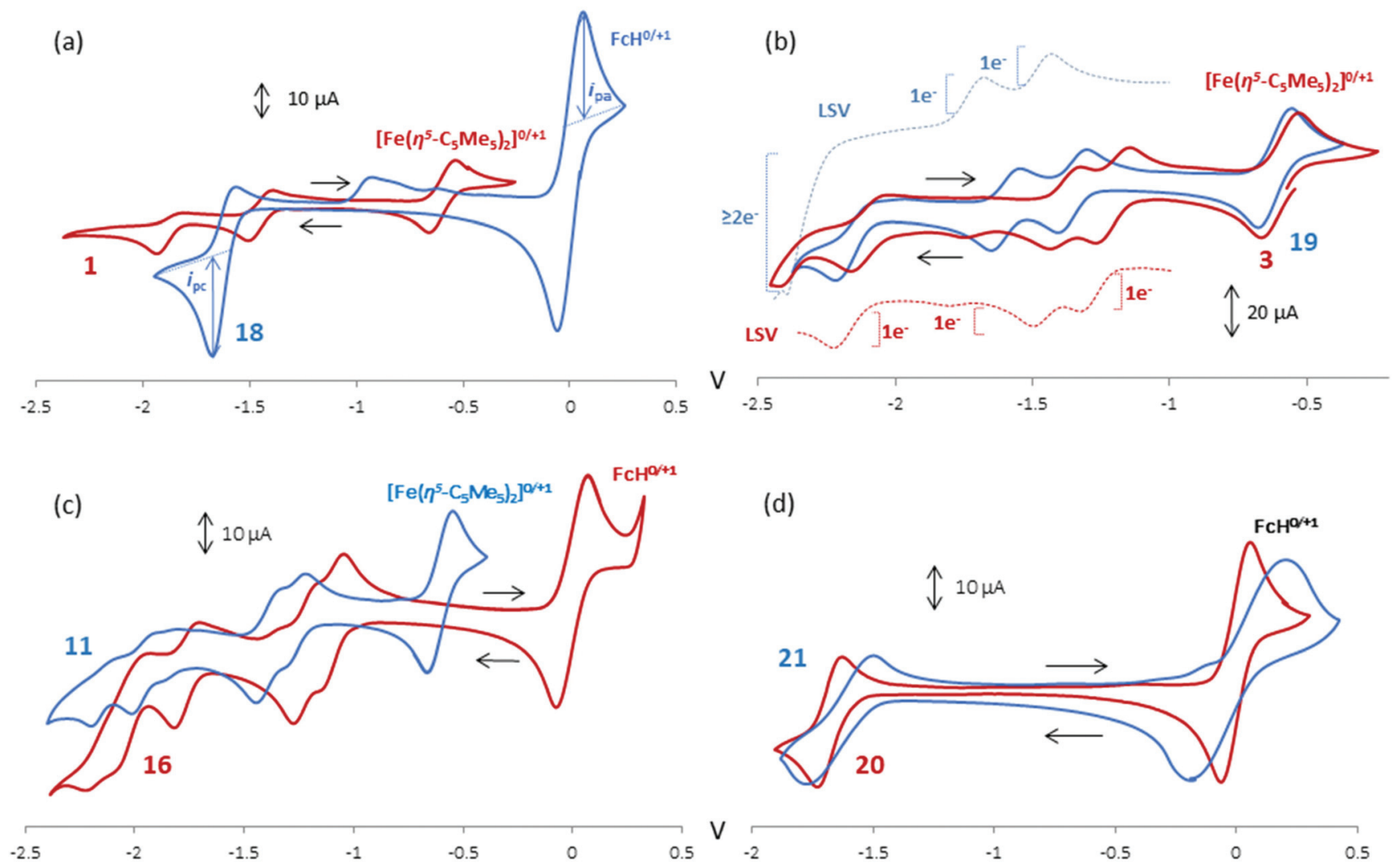

Fig. $6 \mathrm{CVs}$ of the overlapping reduction events of (a) 18 (blue) and 1 (red); (b) 19 (blue) and 3 (red), including LSVs; (c) 11 (blue) and 16 (red), and (d) 21 (blue) and 20 (red).

and that of R4 undetermined, as the reduction occurs at the edge of the solvent potential window.

Compared to 3, 19 has two less-overlapping, one-electron, quasi-reversible peaks (R1 and R2) at more negative potentials. R3 is an irreversible reduction consisting of at least two devoted one-electron transfer processes (see linear sweep voltammetry (LSV), Fig. 6(b)). Compounds $\mathbf{1 1}$ and $\mathbf{1 6}$ (chromium and tungsten analogues, respectively) have very similar CVs (Fig. 6(c)), with the reductions of $\mathbf{1 1}$ at more negative potentials. The CVs show two overlapping one-electron reductions (R1 and R2, quasi-reversible) and two or three one-electron irreversible reductions.

Comparing 20 and 21 (cis-DTT vs. trans-DTT spacer), the CVs are analogous as both compounds show an one-electron quasi-reversible reduction at more or less the same reduction potential, Fig. 6(d). In the case of $\mathbf{2 1}$, a second reduction is observed with $E_{\mathrm{pc}}=-2.30 \mathrm{~V}$, indicating the formation of $\mathbf{2 1}^{-2}$.

Considering the chromium bis-chelated tetracarbene complexes, 3, 11 and 19; 19 with a cis-TT spacer stabilized the $\mathrm{Cr}=\mathrm{C}$ bond more towards reduction (more negative reduction potential). The order from most stabilized is, $\mathbf{1 9}>\mathbf{1 1}$ (transDTT) $>3$ (trans-TT), with $c a .80 \mathrm{mV}$ difference between the compounds. When comparing the chromium and tungsten analogous complexes, $\mathbf{1 1}$ and $\mathbf{1 6}$ respectively, $\mathbf{1 1}$ is reduced at a potential $170 \mathrm{mV}$ more negative. When comparing the cis-
DTT and trans-DTT analogous complexes, 20 and 21 respectively, 20 is reduced at a potential $40 \mathrm{mV}$ more negative.

Molecular orbital and spin density calculations are performed at the dispersion corrected B3LYP-D3/def2-SVP level for $1,3,11,18$ and 19 to assist with assigning the $\mathrm{CV}$ reduction processes and their relative orders (Fig. 7). For the monocarbene complex 18, the LUMO is mainly centered on the vacant $\mathrm{p}_{z}$-atomic orbital of the carbene carbon atom and the additional electron gained upon reduction (R1) occupies this orbital (computed spin density of $0.48 \mathrm{e}$ ).

The orbitals associated with carbene complexes are delocalised over the metal, carbene carbon, and oxygen heteroatom of the ethoxy fragment. ${ }^{42}$ The $\mathrm{Cr}-\mathrm{C}^{--}$species are envisioned as being stabilized by distributing charge and the radical over the conjugated ligand system. From the LUMO of 18, it is clear that the carbene carbon is stabilized with significant contributions of the conjugated carbon atoms and less so by the lone pair on the adjacent sulphur atom of the trans-TT spacer (Fig. 7). The greater negative reduction potential of $\mathbf{1 8}$ is reflected in the energy of its LUMO, which is the highest of the entire series. In the case of the mono-chelated biscarbene complex $\mathbf{1}$, the LUMO is almost equally distributed over both carbene carbon atoms. Subsequent reductions confirm that the two electrons are placed on both carbene carbon atoms (see spin density of $\mathbf{1}^{--}$and HOMO of the reduced $\mathbf{1}^{-2}$ system, 


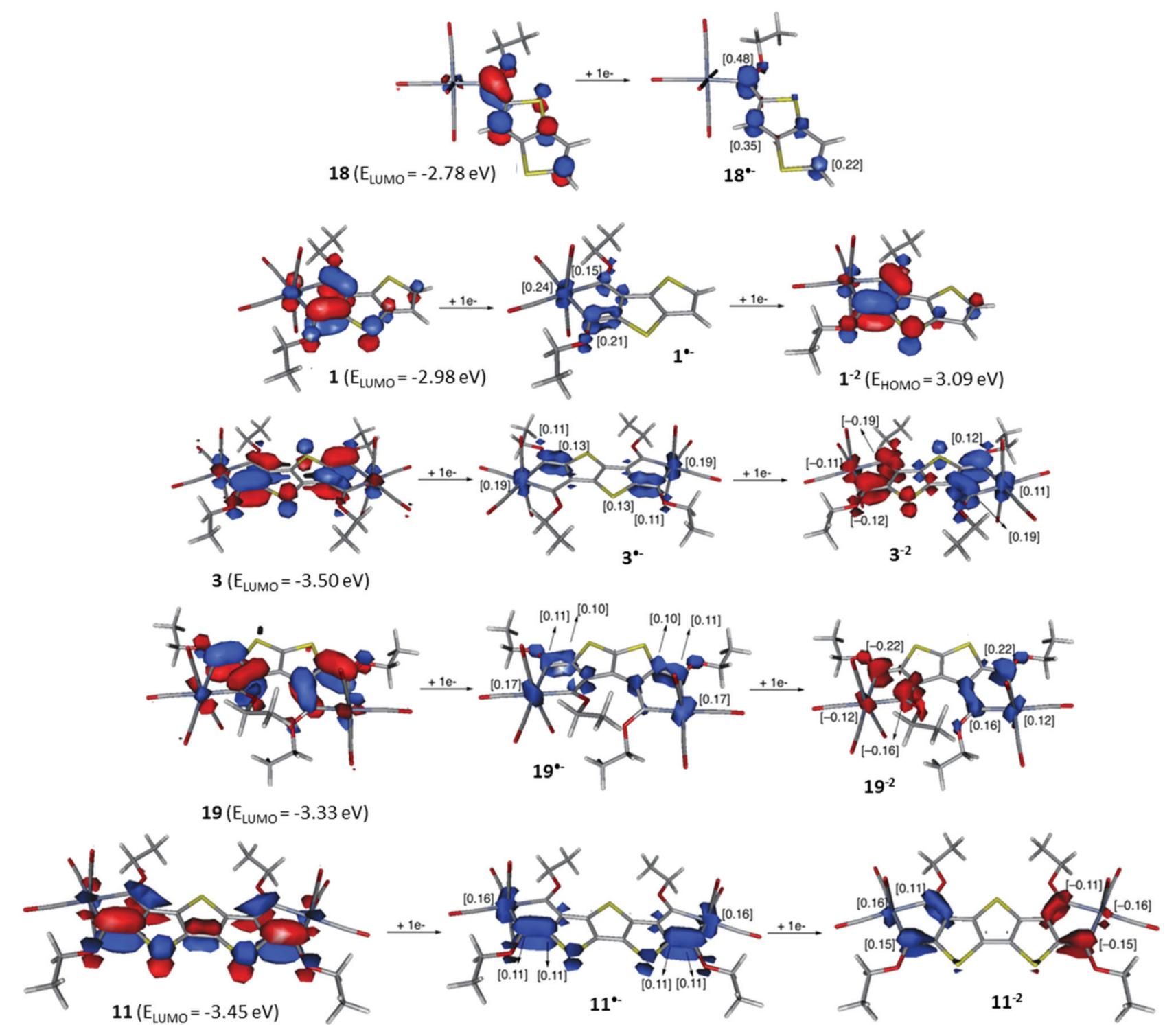

Fig. 7 Summary of spin-density and molecular orbital calculations performed for 18, 1, 3, 19 and 11. All data have been computed at the B3LYP-D3/ def2-SVP level.

Fig. 7). Reductions therefore occur on both carbene carbon centers simultaneously, during the first and second reduction (R1 and R2) and are delocalised over the five-membered metallacyclic ring. According to the more stabilized LUMO of 1, this complex is reduced at lower negative potentials than 18. The LUMO of bis-chelated tetracarbene complex 3 is localized on all carbene carbon atoms, with a larger contribution on the carbene carbon atoms adjacent to the sulphur atoms (C6), as well as on the sulphur atoms in the cis-TT spacer. As a result, the first electron is delocalised over the carbene carbon atoms adjacent to the sulphur atoms. These carbene carbons lie in the conjugated pathway, where they are linked through the thienothienyl with the metal fragments. The second reduction electron leads to the open-shell singlet specie $3^{-2}$ where the unpaired electrons are delocalised across the remote carbene carbon atoms. The third and fourth electrons will presumably complete both singly occupied orbitals to produce a species similar to the reduced closed-shell $\mathbf{1}^{-2}$ system. The reductions are therefore stepwise and site specific. R1 of 3 is assigned to the initial reduction that takes place simultaneously at the two carbene double bonds that neighbour the sulphur atoms in trans-TT. R2 is then assigned as the second reduction that takes place at the carbene double bonds remote to the sulphur atoms in trans-TT. R3 and R4 complete the occupation of open-shell specie $3^{-2}$. Compound 3 exhibits the most stabilized LUMO energy and the second least negative R1 potential (Fig. 7 and Table 4).

Compound 19 and 11 do not show significant differences in their LUMOs and their behaviors are almost identical to that of 3. From the LUMO visualisation of 19 , it is clear that 
the sulphur atoms in the cis-TT spacer do not contribute to the stabilization of the carbene carbon atoms (Fig. 7). Compared to 3 and 11, 19 has a higher LUMO energy accompanying the more negative reduction potential observed.

From the LUMO visualisation of 11, the longer conjugated spacer (trans-DTT) shows contribution of the sulphur atoms adjacent to the carbene carbon atoms, but not the central sulphur atom. A second aspect to consider for the ease of the first reduction in the tetracarbene complexes, is the number of thiophene rings in the linear, conjugated spacer. While $E_{\text {LUMO }}: 3(-3.50 \mathrm{eV})<\mathbf{1 1}(-3.45 \mathrm{eV})$, the first reductions (R1) are: $3\left(E^{\circ \prime}=-1.20 \mathrm{eV}\right)>11(-1.27 \mathrm{eV})$ while the second reductions are more comparable (Table 4$)$.

In this study, no evidence for the formation of mixedvalence electrochemical intermediates showing metal-metal communication is seen upon oxidation or reduction, as observed for ferrocenyl FCCs of chromium. ${ }^{44}$ Rather the complexes behave as simple carbene complexes that accept electrons in their LUMOs, which are more or less conjugated with the thiophene moiety. The LUMO level correlates perfectly with the reduction potential and are indicative of the extent of this conjugation involving the lone pair/s into the empty $\mathrm{p}_{z}$ atomic orbital of the carbene carbon atom. A similar result was found for related extended $\pi$-conjugated Fischer biscarbene complexes. ${ }^{45}$

\section{Conclusions}

Chelated carbene complexes were synthesized from using tetrabromothienylene starting materials. Selective stepwise lithiation with the addition of two equivalents of metal hexacarbonyl, in-between the two dilithiations, followed by alkylation yielded new examples of the rare class of chelated multicarbene complexes of the Fischer-type. The reaction conditions chosen for the preparative route allowed for the targeted bischelated dinuclear tetracarbene complexes as major products. These complexes display either a linear overall molecular geometry when employing the up-down(-up) trans-TT or trans-DTT spacers (e.g. 3, 8, 11 and 16), or the bent/semi-circular molecular geometry of the complexes featuring the up-up-up cisDTT spacer between the terminal metallacyclic bicarbene moieties in 17, similar to the up-up analogue $19 .^{32}$ The two carbene ligands in the chelate ring are clearly electronically different as was confirmed by the DFT calculations and experimentally by different chemical shifts in the corresponding ${ }^{1} \mathrm{H}$ and ${ }^{13} \mathrm{C}$ NMR spectra and the bond distances around the carbene carbons in the solid state structures.

Cyclic voltammetry experiments indicated that the reduction of the chelated carbene complexes result in the negative charge being delocalised over the entire metallacyclic ring (all carbene carbon atoms). The chelated carbene complexes reductions are more facile compared to monodentate carbene complexes, and their LUMO energies lower. In the case of chelated carbene complexes with linear conjugated annulated thienylene spacers (trans-TT and trans-DTT), the electron delocalisation of the negative charge is also over the thienylene carbons and adjacent sulphur atom/s (increasing electron density on the heterocyclic part). The sulphur atom involvement in electron delocalisation contributes to the LUMO of the complexes, causing reduction at less negative potentials, compared to complexes with bent non-conjugated cis-TT and cis-DTT spacers where the contribution of the sulphur atoms is absent and the formed radical-anions do not adopt a planar arrangement with a co-planar carbene carbon. $^{42,43}$ In summary, chelation of the carbene ligands allows for the conjugation of the empty carbene carbon $p_{z}$ orbitals with the aromatic thiophene rings in the formed metallacycles. This effect is enhanced when the ring systems are linear as opposed to bent when the sulphur atoms are oriented cis to each other.

No mixed valence species formed during the stepwise reductions of chelated carbene complexes and no evidence of through-bond electronic communication is observed between the metal-carbene fragments. The individual oxidation and reduction waves are split due only to electrostatic effects. ${ }^{36}$ This is in contrast to the mixed valence species observed for ferrocenyl carbene complexes. ${ }^{44}$

\section{Experimental}

\section{General}

All operations were carried out using standard Schlenk techniques or vacuum line techniques under an inert atmosphere of nitrogen or argon, using oven-dried glassware. Silica gel 60 (particle size $0.063-0.20 \mathrm{~mm}$ ) was used as resin (stationary phase) for all column chromatography separations.

\section{Chemical reagents and solvents}

Triethyloxonium tetrafluoroborate was prepared according to literature procedure and stored in diethyl ether under $\operatorname{Ar}(\mathrm{g}){ }^{46}$ Boron trifluoride etherate was distilled before use. Anhydrous solvents, which were degassed through bubbling $\mathrm{N}_{2}$, were used for experimental procedures. THF and diethyl ether were distilled over sodium wire and benzophenone under $\mathrm{N}_{2}(\mathrm{~g})$ atmosphere, hexane and benzene over sodium wire and DCM over $\mathrm{CaH}_{2}$. Other chemicals were used as they were commercially supplied by Sigma Aldrich and Strem Chemicals. The $n$-BuLi used in syntheses, was from a stock 1.6 M solution in hexane. Compounds 4,4',5,5'-tetrabromo-thieno[3,2-b]thiophene (transTT-Br 4 ), 4, 4',5, $5^{\prime}$-tetrabromo-dithieno[2,3- $b ; 3^{\prime}, 2^{\prime}$ - $\left.d\right]$ thiophene (cis-DTT-Br ${ }_{4}$ ) and $4,4^{\prime}, 5,5^{\prime}$-tetrabromodithieno $\left[3,2-b ; 2^{\prime}, 3^{\prime}-d\right]$ thiophene (trans-DTT- $\mathrm{Br}_{4}$ ) were prepared according to literature procedures. $^{47-49}$ Compounds $18,{ }^{50} \mathbf{1 9},{ }^{32} 20^{51}$ and $21^{35}$ were prepared according to literature procedures, for comparative cyclic voltammetry studies.

\section{Synthesis and characterization of Fischer carbene complexes}

Synthesis of chromium chelated carbene complexes of trans-TT. A solution of trans-TT- $\mathrm{Br}_{4}(1.14 \mathrm{~g}, 2.5 \mathrm{mmol})$ in THF was cooled to $-78{ }^{\circ} \mathrm{C}$ and $n$-BuLi $(4.29 \mathrm{~mL}, 6.0 \mathrm{mmol})$ was 
added. The lithiation happened within minutes, as was indicated by a distinct colour change from yellow to orange. Within five minutes, $\operatorname{Cr}(\mathrm{CO})_{6}(1.10 \mathrm{~g}, 5.0 \mathrm{mmol})$ was added and the solution heated with a hairdryer to room temperature until all the metal carbonyl dissolved, turning the solution red orange. The solution was cooled to $-78{ }^{\circ} \mathrm{C}$ and a second portion $n$-BuLi $(4.29 \mathrm{~mL}, 6.0 \mathrm{mmol})$ was added, resulting in a purple-black solution. The solution was heated to room temperature, changing the colour to brown black. The solvent was removed in vacuo, and the reaction residue was dissolved in $10 \mathrm{~mL}$ DCM and cooled to $-40{ }^{\circ} \mathrm{C}$. $\left[\mathrm{Et}_{3} \mathrm{O}\right]\left[\mathrm{BF}_{4}\right](4.50 \mathrm{~g}$, $23.7 \mathrm{mmol}$ ) dissolved in $10 \mathrm{~mL}$ DCM, was added to the reaction mixture and allowed to rise to room temperature, turning the colour to purple/green-black. Afterwards, most of the solvent was removed in vacuo and the reaction mixture was wet loaded on a silica gel column. Band separation was obtained using gradient elution with hexane and DCM during flash chromatography. The products isolated, in sequence of elution, are listed in Table S1, ESI. $\dagger$ Monometal butylcarbene complex byproduct formation was observed during all the reactions, indicating the reaction of excess $n$-BuLi with the metal hexacarbonyls in the reaction mixtures.

1: UV-Vis $\lambda_{\max }\left(\mathrm{CH}_{2} \mathrm{Cl}_{2}\right) / \mathrm{nm} 618$ and 373, from a sample with $1: 0.6$ of $1: 2$ (not quantitative). FT-IR $\nu_{\mathrm{CO}}$ (hexane) $/ \mathrm{cm}^{-1}$ 2017m $\left(\mathrm{A}_{1}{ }^{(1)}\right)$, 1962s $\left(\mathrm{B}_{1}\right), 1947 \mathrm{~m}\left(\mathrm{~A}_{1}{ }^{(2)}\right), 1895 \mathrm{~m}\left(\mathrm{~B}_{2}\right) .{ }^{1} \mathbf{H}$ NMR $\delta^{1} \mathrm{H}\left(300.13 \mathrm{MHz} ; \mathrm{CDCl}_{3} ; \mathrm{Me}_{4} \mathrm{Si}\right) 7.60\left(1 \mathrm{H}, \mathrm{d},{ }^{3} J_{5^{\prime}, 4^{\prime}} 5.2, \mathrm{H} 5^{\prime}\right)$, $7.21\left(1 \mathrm{H}, \mathrm{d},{ }^{3} J_{4^{\prime}, 5^{\prime}} 5.2, \mathrm{H} 4^{\prime}\right), 4.78\left(2 \mathrm{H}, \mathrm{q},{ }^{3} J 7.1, \mathrm{C}^{2} \mathrm{CH}_{2}\right), 4.72(2$ $\left.\mathrm{H}, \mathrm{q},{ }^{3} \mathrm{~J} 7.1, \mathrm{C} \mathrm{CH}_{2}\right), 1.70\left(3 \mathrm{H}, \mathrm{t},{ }^{3} \mathrm{~J} 7.1, \mathrm{C} \mathrm{CH}_{3}\right), 1.61\left(3 \mathrm{H}, \mathrm{t},{ }^{3} \mathrm{~J}\right.$ 7.1, $\left.\mathrm{C}_{6} \mathrm{CH}_{3}\right) .{ }^{13} \mathrm{C}$ NMR $\delta^{13} \mathrm{C}\left(100.613 \mathrm{MHz} ; \mathrm{CDCl}_{3} ; \mathrm{Me}_{4} \mathrm{Si}\right) 314.4$ $\left(\mathrm{C} 7_{\text {carb }}\right), 309.2\left(\mathrm{C}_{\text {carb }}\right), 243.0$ and $242.9\left(\mathrm{CO}_{\text {trans }}\right), 227.8\left(\mathrm{CO}_{\text {cis }}\right)$, 163.4 (C5), 157.0 (C4), 145.7 and 127.7 (C3 and C2), 132.8 (C5'), $120.0\left(\mathrm{C}^{\prime}\right)$, n.o. $\left(\mathrm{C}^{\prime} \mathrm{CH}_{2}\right), 76.4\left(\mathrm{C}^{\prime} \mathrm{CH}_{2}\right), 15.1\left(\mathrm{C}^{2} \mathrm{CH}_{3}\right.$ and $\left.\mathrm{C}_{6} \mathrm{CH}_{3}\right)$.

2: UV-Vis $\lambda_{\max }\left(\mathrm{CH}_{2} \mathrm{Cl}_{2}\right) / \mathrm{nm} 614$ and 366, compound decomposed in solution (not quantitative). FT-IR $\nu_{\text {CO }}$ (hexane) $/ \mathrm{cm}^{-1}$ 2018m $\left(\mathrm{A}_{1}{ }^{(1)}\right)$, 1962s $\left(\mathrm{B}_{1}\right), 1947 \mathrm{~m}\left(\mathrm{~A}_{1}{ }^{(2)}\right), 1896 \mathrm{~m}\left(\mathrm{~B}_{2}\right) .{ }^{1} \mathbf{H}$ NMR $\delta^{1} \mathrm{H}\left(300.13 \mathrm{MHz} ; \mathrm{CDCl}_{3} ; \mathrm{Me}_{4} \mathrm{Si}\right) 4.74\left(2 \mathrm{H}, \mathrm{q},{ }^{3} J 6.8, \mathrm{C}^{\mathrm{C}} \mathrm{CH}_{2}\right)$, $4.69\left(2 \mathrm{H}, \mathrm{q},{ }^{3} J 7.0, \mathrm{C} \mathrm{CH}_{2}\right), 1.68\left(3 \mathrm{H}, \mathrm{t},{ }^{3} \mathrm{~J} 6.8, \mathrm{C} \mathrm{CH}_{3}\right), 1.60(3$ $\left.\mathrm{H}, \mathrm{t},{ }^{3} \mathrm{~J} 7.0, \mathrm{C} \mathrm{CH}_{3}\right), 2.87\left(2 \mathrm{H}, \mathrm{t},{ }^{3} J \mathrm{~J} .5, \mathrm{CH}_{2} \mathrm{CH}_{2} \mathrm{CH}_{2} \mathrm{CH}_{3}\right)$, 1.76-1.67 (2 H, m, $\left.\mathrm{CH}_{2} \mathrm{CH}_{2} \mathrm{CH}_{2} \mathrm{CH}_{3}\right), 1.50-1.37(2 \mathrm{H}, \mathrm{m}$, $\left.\mathrm{CH}_{2} \mathrm{CH}_{2} \mathrm{CH}_{2} \mathrm{CH}_{3}\right), 0.97\left(3 \mathrm{H}, \mathrm{t},{ }^{3} \mathrm{~J} 7.3, \mathrm{CH}_{2} \mathrm{CH}_{2} \mathrm{CH}_{2} \mathrm{CH}_{3}\right) .{ }^{13} \mathrm{C}$ NMR $\delta^{13} \mathrm{C}\left(75.468 \mathrm{MHz} ; \mathrm{CDCl}_{3} ; \mathrm{Me}_{4} \mathrm{Si}\right) 315.0\left(\mathrm{C}_{\text {carb }}\right), 308.2$ (C6 $\left.6_{\text {carb }}\right), 243.2$ and $242.8\left(\mathrm{CO}_{\text {trans }}\right), 227.8\left(\mathrm{CO}_{\text {cis }}\right), 160.8$ (C5), 157.2 (C4), 147.4 and 124.0 (C3 and $\mathrm{C} 2$ ), 148.3 (C5'), 101.9 $\left(\mathrm{C}^{\prime}\right)$, n.o. $\left(\mathrm{C}^{\mathrm{CH}} \mathrm{CH}_{2}\right), 76.4\left(\mathrm{C}^{2} \mathrm{CH}_{2}\right), 15.0\left(\mathrm{C}^{2} \mathrm{CH}_{3}\right.$ and $\left.\mathrm{C}_{6-\mathrm{CH}_{3}}\right)$, $30.3 \quad\left(\mathrm{CH}_{2} \mathrm{CH}_{2} \mathrm{CH}_{2} \mathrm{CH}_{3}\right), \quad 32.5 \quad\left(\mathrm{CH}_{2} \mathrm{CH}_{2} \mathrm{CH}_{2} \mathrm{CH}_{3}\right), \quad 22.1$ $\left(\mathrm{CH}_{2} \mathrm{CH}_{2} \mathrm{CH}_{2} \mathrm{CH}_{3}\right), 13.7\left(\mathrm{CH}_{2} \mathrm{CH}_{2} \mathrm{CH}_{2} \mathrm{CH}_{3}\right)$.

3: UV-Vis $\lambda_{\max }\left(\mathrm{CH}_{2} \mathrm{Cl}_{2}\right) / \mathrm{nm} 683\left(\varepsilon / \mathrm{dm}^{3} \mathrm{~mol}^{-1} \mathrm{~cm}^{-1} 9770\right)$, 453 (10 170), 393 (28 240). FT-IR $\nu_{\mathrm{CO}}$ (hexane) $/ \mathrm{cm}^{-1} 2018 \mathrm{~m}$ $\left(\mathrm{A}_{1}^{(1)}\right), 1962 \mathrm{~s}\left(\mathrm{~B}_{1}\right), 1947 \mathrm{~m}\left(\mathrm{~A}_{1}^{(2)}\right), 1895 \mathrm{~m}\left(\mathrm{~B}_{2}\right) \cdot \nu_{\mathrm{CO}}(\mathrm{DCM}) / \mathrm{cm}^{-1}$ $2010 \mathrm{~m}\left(\mathrm{~A}_{1}^{(1)}\right), 1959 \mathrm{~s}\left(\mathrm{~B}_{1}\right), 1938 \mathrm{~m}\left(\mathrm{~A}_{1}^{(2)}\right), 1884 \mathrm{~m}\left(\mathrm{~B}_{2}\right) . \delta^{1} \mathrm{H}$ (400.13 MHz; $\left.\mathrm{CDCl}_{3} ; \mathrm{Me}_{4} \mathrm{Si}\right) 4.71\left(4 \mathrm{H}, \mathrm{q},{ }^{3} J 7.1, \mathrm{C} \mathrm{CH}_{2}\right), 4.70$ $\left(4 \mathrm{H}, \mathrm{q},{ }^{3} \mathrm{~J} 7.1, \mathrm{C}_{6} \mathrm{CH}_{2}\right), 1.67\left(6 \mathrm{H}, \mathrm{t},{ }^{3} J 7.1, \mathrm{C} \mathrm{CH}_{3}\right), 1.62(6 \mathrm{H}, \mathrm{t}$,


314.6 (C7 $\left.7_{\text {carb }}\right), 310.0$ ( $\left.6_{\text {carb }}\right), 244.8$ and $242.4\left(\mathrm{CO}_{\text {trans }}\right), 227.5$ $\left(\mathrm{CO}_{c i s}\right), 165.0(\mathrm{C} 5), 157.8(\mathrm{C} 4), 131.6$ and 129.2 (C3 and C2), n. o. $\left(\mathrm{C} \mathrm{CH}_{2}\right.$ and $\left.\mathrm{C}_{6} \mathrm{CH}_{2}\right), 15.1\left(\mathrm{C}^{2} \mathrm{CH}_{3}\right.$ and $\left.\mathrm{C}_{6} \mathrm{CH}_{3}\right)$. HR-MS $\mathrm{m} / \mathrm{z}$ $\left(\mathrm{C}_{26} \mathrm{H}_{20} \mathrm{O}_{12} \mathrm{~S}_{2} \mathrm{Cr}_{2}, 692.55 \mathrm{~g} \mathrm{~mol}^{-1}\right)$ calculated: 662.9179, found: $662.9341\left(5 \%,[\mathrm{M}-\mathrm{H}-\mathrm{CO}]^{-}\right)$, calculated: 634.9230 , found: $634.9350\left(5 \%,[\mathrm{M}-\mathrm{H}-2 \mathrm{CO}]^{-}\right)$.

4: ${ }^{1} \mathrm{H}$ NMR $\delta^{1} \mathrm{H}\left(400.13 \mathrm{MHz} ; \mathrm{CDCl}_{3} ; \mathrm{Me}_{4} \mathrm{Si}\right) 8.91(1 \mathrm{H}, \mathrm{s}$, $\left.\mathrm{H} 4^{\prime}\right), 4.75\left(2 \mathrm{H}, \mathrm{q},{ }^{3} J 7.0, \mathrm{C} \mathrm{CH}_{2}\right), 4.72\left(2 \mathrm{H}, \mathrm{q},{ }^{3} J 7.1, \mathrm{C}^{2} \mathrm{CH}_{2}\right)$, $5.34\left(2 \mathrm{H}, \mathrm{q},{ }^{3} J 7.0, \mathrm{C}^{\prime} \mathrm{CH}_{2}\right), 1.70\left(3 \mathrm{H}, \mathrm{t},{ }^{3} J\right.$ 7.0, $\left.\mathrm{C}^{2} \mathrm{CH}_{3}\right), 1.62(3$ $\left.\mathrm{H}, \mathrm{t},{ }^{3} \mathrm{~J} 7.0, \mathrm{C}_{6} \mathrm{CH}_{3}\right), 1.86\left(3 \mathrm{H}, \mathrm{t},{ }^{3} \mathrm{~J} 7.0, \mathrm{C} 6^{\prime} \mathrm{CH}_{3}\right) .{ }^{13} \mathrm{C}$ NMR $\delta^{13} \mathrm{C}$ (75.468 MHz; $\left.\mathrm{CDCl}_{3} ; \mathrm{Me}_{4} \mathrm{Si}\right) 314.6$ ( $\left.\mathrm{C}_{\text {carb }}\right), 310.9\left(\mathrm{C}_{\text {carb }}\right), 321.7$ (C6 ${ }^{\prime}$ carb), 243.3 and $243.0\left((\mathrm{CO})_{4}\right.$ trans $), 227.8\left((\mathrm{CO})_{4}\right.$ cis $), 222.9$ $\left((\mathrm{CO})_{5}\right.$ trans $), 216.8\left((\mathrm{CO})_{5}\right.$ cis $), 149.3,147.0$ and the rest n.o. (C5, $\left.\mathrm{C} 4, \mathrm{C} 3, \mathrm{C} 2, \mathrm{C}^{\prime}, \mathrm{C} 4{ }^{\prime}\right)$, n.o. $\left(\mathrm{C}^{-} \mathrm{CH}_{2}, \mathrm{C} \mathrm{CH}_{2}\right.$ and $\left.\mathrm{C}^{\prime} \mathrm{CH}_{2}\right), 15.1$ $\left(\mathrm{C}^{2} \mathrm{CH}_{3}\right), 15.0\left(\mathrm{C}^{2} \mathrm{CH}_{3}\right), 15.8\left(\mathrm{C6}^{\prime} \mathrm{CH}_{3}\right)$.

Synthesis of tungsten chelated carbene complexes of trans-TT. The same reaction as for the preparation of 1-4 was applied, only now $\mathrm{W}(\mathrm{CO})_{6}(1.76 \mathrm{~g}, 5.0 \mathrm{mmol})$ was added instead of the chromium precursor. The products isolated are listed in Table S2, ESI. $\dagger$

5: UV-Vis $\lambda_{\max }\left(\mathrm{CH}_{2} \mathrm{Cl}_{2}\right) / \mathrm{nm} 600\left(\varepsilon / \mathrm{dm}^{3} \mathrm{~mol}^{-1} \mathrm{~cm}^{-1} 6760\right)$,

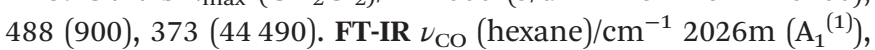
$1955 \mathrm{~s} \quad\left(\mathrm{~B}_{1}\right), \quad 1942 \mathrm{~m} \quad\left(\mathrm{~A}_{1}{ }^{(2)}\right), \quad 1889 \mathrm{~m} \quad\left(\mathrm{~B}_{2}\right) .{ }^{1} \mathbf{H} \quad \mathbf{N M R} \quad \delta^{1} \mathrm{H}$ (400.13 MHz; $\left.\mathrm{CDCl}_{3} ; \mathrm{Me}_{4} \mathrm{Si}\right) 7.71\left(1 \mathrm{H}, \mathrm{d},{ }^{3} J_{5^{\prime}, 4^{\prime}} 5.3, \mathrm{H} 5^{\prime}\right), 7.20$ (1 $\left.\mathrm{H}, \mathrm{d},{ }^{3} J_{4^{\prime}, 5^{\prime}} 5.3, \mathrm{H} 4^{\prime}\right), 4.54\left(2 \mathrm{H}, \mathrm{q},{ }^{3} J 7.1, \mathrm{C}^{2} \mathrm{CH}_{2}\right), 4.50\left(2 \mathrm{H}, \mathrm{q},{ }^{3} J\right.$


$\left.\mathrm{C} \mathrm{CH}_{3}\right) \cdot{ }^{13} \mathrm{C}$ NMR $\delta^{13} \mathrm{C}\left(100.613 \mathrm{MHz} ; \mathrm{CDCl}_{3} ; \mathrm{Me}_{4} \mathrm{Si}\right) 286.8$ $\left(\mathrm{C}_{\text {carb }}\right), 282.7$ ( $\left.\mathrm{C}_{\text {carb }}\right), 220.5$ and $220.2\left(\mathrm{CO}_{\text {trans }}\right), 212.5\left(\mathrm{CO}_{\text {cis }}\right)$, 169.6 (C5), 161.3 (C4), 145.8 and 128.8 (C3 and $\mathrm{C} 2$ ), 133.0 (C5'), $120.4\left(\mathrm{C} 4^{\prime}\right), 79.7\left(\mathrm{C}^{2} \mathrm{CH}_{2}\right), 79.5\left(\mathrm{C}^{2} \mathrm{CH}_{2}\right), 14.8\left(\mathrm{C}^{-1} \mathrm{CH}_{3}\right)$, $14.7\left(\mathrm{C}_{6} \mathrm{CH}_{3}\right)$. HR-MS $m / z\left(\mathrm{C}_{16} \mathrm{H}_{12} \mathrm{O}_{6} \mathrm{~S}_{2} \mathrm{~W}, 548.23 \mathrm{~g} \mathrm{~mol}^{-1}\right)$ calculated: 546.9507 , found: $546.9580\left(8 \%,[\mathrm{M}-\mathrm{H}]^{-}\right)$, calculated: 518.9557, found: $518.9627\left(16 \%,[\mathrm{M}-\mathrm{H}-\mathrm{CO}]^{-}\right)$, calculated: 462.9659, found: $\left.462.9383(8 \% \text {, [M }-\mathrm{H}-3 \mathrm{CO}]^{-}\right)$.

6: 6H $1: 2$ 6Br. ${ }^{1} \mathbf{H}$ NMR $\delta^{1} \mathrm{H}$ 6H $\left(400.13 \mathrm{MHz} ; \mathrm{CDCl}_{3} ; \mathrm{Me}_{4} \mathrm{Si}\right)$ $7.56\left(1 \mathrm{H}, \mathrm{s}, \mathrm{H} 4^{\prime}\right), 4.50\left(2 \mathrm{H}, \mathrm{q},{ }^{3} J 6.8, \mathrm{C}^{2} \mathrm{CH}_{2}\right), 4.48\left(2 \mathrm{H}, \mathrm{q},{ }^{3} J\right.$

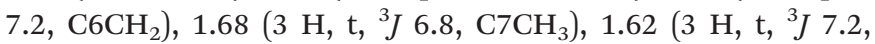
$\left.\mathrm{C}_{6} \mathrm{CH}_{3}\right), 2.82\left(2 \mathrm{H}, \mathrm{t},{ }^{3} \mathrm{~J} 7.3, \mathrm{CH}_{2} \mathrm{CH}_{2} \mathrm{CH}_{2} \mathrm{CH}_{3}\right), 1.71(2 \mathrm{H}, \mathrm{m}$, $\left.\mathrm{CH}_{2} \mathrm{CH}_{2} \mathrm{CH}_{2} \mathrm{CH}_{3}\right), 1.44\left(2 \mathrm{H}, \mathrm{tq},{ }^{3} J 7.3, \mathrm{CH}_{2} \mathrm{CH}_{2} \mathrm{CH}_{2} \mathrm{CH}_{3}\right), 0.97$ $\left(3 \mathrm{H}, \mathrm{t},{ }^{3} \mathrm{~J} 7.3, \mathrm{CH}_{2} \mathrm{CH}_{2} \mathrm{CH}_{2} \mathrm{CH}_{3}\right) . \delta^{1} \mathrm{H} 6 \mathrm{Br}\left(400.13 \mathrm{MHz} ; \mathrm{CDCl}_{3}\right.$; $\left.\mathrm{Me}_{4} \mathrm{Si}\right) 4.51\left(2 \mathrm{H}, \mathrm{q},{ }^{3} \mathrm{~J} 7.0, \mathrm{C}_{\mathrm{CH}}\right), 4.48\left(2 \mathrm{H}, \mathrm{q},{ }^{3} \mathrm{~J} 7.2, \mathrm{C} \mathrm{CH}_{2}\right)$, $1.69\left(3 \mathrm{H}, \mathrm{t},{ }^{3} \mathrm{~J} 7.0, \mathrm{C}_{\mathrm{CH}}\right), 1.61\left(3 \mathrm{H}, \mathrm{t},{ }^{3} \mathrm{~J} 7.2, \mathrm{C} \mathrm{CH}_{3}\right), 2.82(2$ $\left.\mathrm{H}, \mathrm{t},{ }^{3} \mathrm{~J} 7.3, \mathrm{CH}_{2} \mathrm{CH}_{2} \mathrm{CH}_{2} \mathrm{CH}_{3}\right), 1.69\left(2 \mathrm{H}, \mathrm{m}, \mathrm{CH}_{2} \mathrm{CH}_{2} \mathrm{CH}_{2} \mathrm{CH}_{3}\right)$, $1.44\left(2 \mathrm{H}, \mathrm{tq},{ }^{3} \mathrm{~J} 7.3, \mathrm{CH}_{2} \mathrm{CH}_{2} \mathrm{CH}_{2} \mathrm{CH}_{3}\right), 0.97\left(3 \mathrm{H}, \mathrm{t},{ }^{3} \mathrm{~J} 7.3\right.$, $\left.\mathrm{CH}_{2} \mathrm{CH}_{2} \mathrm{CH}_{2} \mathrm{CH}_{3}\right)$.

7: UV-Vis $\lambda_{\max }\left(\mathrm{CH}_{2} \mathrm{Cl}_{2}\right) / \mathrm{nm} 600\left(\varepsilon / \mathrm{dm}^{3} \mathrm{~mol}^{-1} \mathrm{~cm}^{-1} 6180\right)$, 443 (7020), 378 (39 740). FT-IR $\nu_{\mathrm{CO}}$ (hexane) $/ \mathrm{cm}^{-1} \mathrm{M}(\mathrm{CO})_{5}$ : 2066m $\left(\mathrm{A}_{1}^{(1)}\right), 1983$ and 1976vw $\left(\mathrm{B}_{1}\right), 1940 \mathrm{~s}\left(\mathrm{E}\right.$ and $\mathrm{A}_{1}^{\left({ }^{(2)}\right)}$, $\mathrm{M}(\mathrm{CO})_{4}$ : 2024m $\left(\mathrm{A}_{1}^{(1)}\right)$, 1950s $\left(\mathrm{B}_{1}\right), 1940 \mathrm{~s}\left(\mathrm{~A}_{1}{ }^{(2)}\right)$, 1884m $\left(\mathrm{B}_{2}\right)$. $\nu_{\mathrm{CO}}(\mathrm{DCM}) / \mathrm{cm}^{-1} \mathrm{M}(\mathrm{CO})_{5}: 2064 \mathrm{~m}\left(\mathrm{~A}_{1}^{(1)}\right), 1972 \mathrm{vw}\left(\mathrm{B}_{1}\right), 1927 \mathrm{~s}(\mathrm{E}$ and $\left.\mathrm{A}_{1}{ }^{(2)}\right), \mathrm{M}(\mathrm{CO})_{4}$ : 2019m $\left(\mathrm{A}_{1}^{(1)}\right)$, 1938s $\left(\mathrm{B}_{1}\right), 1927 \mathrm{~s}\left(\mathrm{~A}_{1}^{(2)}\right)$, $1862 \mathrm{~m}\left(\mathrm{~B}_{2}\right) .{ }^{1} \mathrm{H}$ NMR $\delta^{1} \mathrm{H}\left(400.13 \mathrm{MHz} ; \mathrm{CDCl}_{3} ; \mathrm{Me}_{4} \mathrm{Si}\right) 4.54(2$ $\mathrm{H}, \mathrm{q},{ }^{3} J$ 7.1, $\left.\mathrm{C} \mathrm{CH}_{2}\right), 4.47\left(2 \mathrm{H}, \mathrm{q},{ }^{3} J\right.$ 7.1, $\left.\mathrm{C}_{6} \mathrm{CH}_{2}\right), 5.06(2 \mathrm{H}, \mathrm{q}$, ${ }^{3} J$ 7.1, $\left.\mathrm{C}^{\prime} \mathrm{CH}_{2}\right), 4.12\left(2 \mathrm{H}, \mathrm{q},{ }^{3} J\right.$ 6.9, $\left.\mathrm{C}^{\prime} \mathrm{CH}_{2}\right), 2.49-2.33(2 \mathrm{H}, \mathrm{m}$, $\left.\mathrm{C}^{\prime} \mathrm{CH}_{2}\right), 2.16\left(2 \mathrm{H}, \mathrm{q},{ }^{3} J\right.$ 7.3, $\left.\mathrm{C}^{\prime} \mathrm{CH}_{2}\right), 1.69\left(6 \mathrm{H}, \mathrm{t},{ }^{3} J\right.$ 7.1, $\mathrm{C}^{2} \mathrm{CH}_{3}$ and $\left.\mathrm{C}^{\prime} \mathrm{CH}_{3}\right), 1.59\left(3 \mathrm{H}, \mathrm{t},{ }^{3} \mathrm{~J} 7.1, \mathrm{C}^{2} \mathrm{CH}_{3}\right), 1.44\left(3 \mathrm{H}, \mathrm{t},{ }^{3} \mathrm{~J}\right.$ 6.9, $\left.\mathrm{C} 5^{\prime} \mathrm{CH}_{3}\right), 0.71\left(6 \mathrm{H}, \mathrm{t},{ }^{3} J\right.$ 7.1, $\left.\mathrm{C}^{\prime}\left(\mathrm{CH}_{3}\right)_{2}\right) .{ }^{13} \mathrm{C}$ NMR $\delta^{13} \mathrm{C}$ (100.613 MHz; $\left.\mathrm{CDCl}_{3} ; \mathrm{Me}_{4} \mathrm{Si}\right) 287.5$ ( $\left.\mathrm{C}_{\text {carb }}\right), 278.8$ ( $\left.6_{\text {carb }}\right)$, 
341.9 (C6' $\left.{ }_{\text {carb }}\right), 221.7$ and $219.2\left(\mathrm{CO}_{4}\right.$ trans $), 212.4\left(\mathrm{CO}_{4}\right.$ cis $), 200.9$ $\left(\mathrm{CO}_{5}\right.$ trans $), 197.2\left(\mathrm{CO}_{5}\right.$ cis $), 163.6$ (C5), 161.9 (C4), 119.0 and 114.9 (C3 and C2), 165.4 (C5'), $147.1\left(\mathrm{C}^{\prime}\right), 79.7\left(\mathrm{C}^{\prime} \mathrm{CH}_{2}\right), 79.1$ $\left(\mathrm{C}^{2} \mathrm{CH}_{2}\right), 81.5\left(\mathrm{C6}^{\prime} \mathrm{CH}_{2}\right), 70.7\left(\mathrm{C}^{\prime} \mathrm{CR}_{3}\right), 70.1\left(\mathrm{C}^{\prime} \mathrm{CH}_{2}\right), 26.8\left(\mathrm{C}^{\prime}\right.$ $\left.\left(\mathrm{CH}_{2}\right)_{2}, \mathrm{br}\right), 14.8\left(\mathrm{C}^{-\mathrm{CH}_{3}}\right.$ and $\left.\mathrm{C}^{2} \mathrm{CH}_{3}, \mathrm{br}\right), 14.7\left(\mathrm{C}^{\prime} \mathrm{CH}_{3}\right.$ and $\mathrm{C6}^{\prime}$ $\mathrm{CH}_{3}$, br), $9.1\left(\mathrm{C}^{\prime}\left(\mathrm{CH}_{3}\right)_{2}\right.$, br $)$. HR-MS $m / z\left(\mathrm{C}_{31} \mathrm{H}_{30} \mathrm{O}_{13} \mathrm{~S}_{2} \mathrm{~W}_{2}\right.$, $\left.1042.38 \mathrm{~g} \mathrm{~mol}^{-1}\right)$ calculated: 1041.0069 , found: 1041.0203 (14\%, $\left.[\mathrm{M}-\mathrm{H}]^{-}\right)$, calculated: 1013.0120, found: 1013.0165 (7\%, [M $\left.-\mathrm{H}-\mathrm{CO}]^{-}\right)$, calculated: 985.0170 , found: $985.0019(7 \%,[\mathrm{M}$ $-\mathrm{H}-2 \mathrm{CO}]^{-}$).

8: ${ }^{1} \mathrm{H}$ NMR $\delta^{1} \mathrm{H}\left(400.13 \mathrm{MHz} ; \mathrm{CDCl}_{3} ; \mathrm{Me}_{4} \mathrm{Si}\right) 4.56\left(4 \mathrm{H}, \mathrm{q},{ }^{3} \mathrm{~J}\right.$ 7.1, $\mathrm{C} \mathrm{CH}_{2}$ ), 4.48 (4 H, q, ${ }^{3} J$ 7.1, $\left.\mathrm{C} \mathrm{CH}_{2}\right), 1.71\left(6 \mathrm{H}, \mathrm{t},{ }^{3} J\right.$ 7.1, $\left.\mathrm{C} \mathrm{CH}_{3}\right), 1.60\left(6 \mathrm{H}, \mathrm{t},{ }^{3} \mathrm{~J} 7.1, \mathrm{C} \mathrm{CH}_{3}\right)$.

Synthesis of chromium chelated carbene complexes of dithieno[3,2-b;2', $\left.\mathbf{3}^{\prime}-\boldsymbol{d}\right]$ thiophene. The same reaction as for the preparation of 1-4 was applied to trans-DTT-Br ${ }_{4}(1.28 \mathrm{~g}$, $2.5 \mathrm{mmol}$ ). The products isolated, in sequence of elution, are listed in Table S3, ESI. $\dagger$

9: ${ }^{1} \mathrm{H}$ NMR $\delta^{1} \mathrm{H}\left(400.13 \mathrm{MHz} ; \mathrm{CDCl}_{3} ; \mathrm{Me}_{4} \mathrm{Si}\right) 7.55$ (1 H, d, $\left.{ }^{3} J_{5^{\prime}, 4^{\prime}} 4.5, \mathrm{H} 5^{\prime}\right), 7.31$ (1 H, d, $\left.{ }^{3} J_{4^{\prime}, 5^{\prime}} 4.5, \mathrm{H} 4^{\prime}\right), 4.78$ (2 H, q, ${ }^{3} J 7.0$, $\left.\mathrm{C}^{2} \mathrm{CH}_{2}\right), 4.71\left(2 \mathrm{H}, \mathrm{q},{ }^{3} \mathrm{~J} 7.2, \mathrm{C} \mathrm{CH}_{2}\right), 1.72\left(3 \mathrm{H}, \mathrm{t},{ }^{3} \mathrm{~J} 7.0\right.$, $\left.\mathrm{C} \mathrm{CH}_{3}\right), 1.61\left(3 \mathrm{H}, \mathrm{t},{ }^{3} \mathrm{~J} 7.2, \mathrm{C} \mathrm{CH}_{3}\right)$.

11: $\lambda_{\max }\left(\mathrm{CH}_{2} \mathrm{Cl}_{2}\right) / \mathrm{nm} \mathrm{648,446}$ and 387 , (not quantitative). $\nu_{\mathrm{CO}}$ (hexane) $/ \mathrm{cm}^{-1} 2015 \mathrm{~m}\left(\mathrm{~A}_{1}^{(1)}\right), 1968 \mathrm{~s}\left(\mathrm{~B}_{1}\right), 1949 \mathrm{~m}\left(\mathrm{~A}_{1}{ }^{(2)}\right)$, $1901 \mathrm{~m}\left(\mathrm{~B}_{2}\right) . \delta^{1} \mathrm{H}\left(400.13 \mathrm{MHz} ; \mathrm{CDCl}_{3} ; \mathrm{Me}_{4} \mathrm{Si}\right) 4.77\left(4 \mathrm{H}, \mathrm{q},{ }^{3} J\right.$ 7.0, $\mathrm{C} \mathrm{CH}_{2}$ ), 4.70 (4 H, q, ${ }^{3} J$ 7.0, $\left.\mathrm{C}_{6} \mathrm{CH}_{2}\right), 1.71\left(6 \mathrm{H}, \mathrm{t},{ }^{3} J\right.$ 7.0, $\left.\mathrm{C} \mathrm{CH}_{3}\right), 1.61\left(6 \mathrm{H}, \mathrm{t},{ }^{3} J\right.$ 7.0, $\left.\mathrm{C}_{6 \mathrm{CH}}\right) . \delta^{13} \mathrm{C}\left(75.468 \mathrm{MHz} ; \mathrm{CDCl}_{3}\right.$; $\left.\mathrm{Me}_{4} \mathrm{Si}\right) 314.4$ (C7 $\left.7_{\text {carb }}\right), 308.0$ (C6 $\left.6_{\text {carb}}\right), 243.9$ and 242.7 ( $\left.\mathrm{CO}_{\text {trans }}\right)$, $227.6\left(\mathrm{CO}_{\text {cis }}\right), 162.4$ (C5), 157.6 (C4), 137.3 and 132.5 (C3 and C2), $76.7\left(\mathrm{C}^{-\mathrm{CH}_{2}}\right)$, n.o. $\left(\mathrm{C} \mathrm{CH}_{2}\right), 15.0$ and $15.0\left(\mathrm{C}^{2} \mathrm{CH}_{3}\right.$ and $\left.\mathrm{C}_{6} \mathrm{CH}_{3}\right) . m / z \quad\left(\mathrm{C}_{28} \mathrm{H}_{20} \mathrm{O}_{12} \mathrm{~S}_{3} \mathrm{Cr}_{2}, 748.64 \mathrm{~g} \mathrm{~mol}^{-1}\right)$ calculated: 746.8849, found: $746.8924\left(5 \%,[\mathrm{M}-\mathrm{H}]^{-}\right)$, calculated: 718.8900, found: 718.8957 (28\%, $\left.[\mathrm{M}-\mathrm{H}-\mathrm{CO}]^{-}\right)$, calculated: 690.8951, found: $690.9036\left(26 \%,[\mathrm{M}-\mathrm{H}-2 \mathrm{CO}]^{-}\right)$.

Synthesis of tungsten chelated carbene complexes of dithieno[3,2-b;2',3'-d] thiophene. The same reaction as for the preparation of 1-4 was applied to trans-DTT-Br ${ }_{4}(1.28 \mathrm{~g}$, $2.5 \mathrm{mmol})$ and $\mathrm{W}(\mathrm{CO})_{6}(1.76 \mathrm{~g}, 5.0 \mathrm{mmol})$. The products isolated, in sequence of elution, are listed in Table S4, ESI. $\dagger$

12: ${ }^{1} \mathrm{H}$ NMR $\delta^{1} \mathrm{H}\left(400.13 \mathrm{MHz} ; \mathrm{CDCl}_{3} ; \mathrm{Me}_{4} \mathrm{Si}\right) 7.60(1 \mathrm{H}, \mathrm{d}$, $\left.{ }^{3} J_{5^{\prime}, 4^{\prime}} 5.2, \mathrm{H} 5^{\prime}\right), 7.32\left(1 \mathrm{H}, \mathrm{d},{ }^{3} J_{4^{\prime}, 5^{\prime}} 5.2, \mathrm{H} 4^{\prime}\right), 4.55\left(2 \mathrm{H}, \mathrm{q},{ }^{3} J 7.1\right.$, $\left.\mathrm{C} \mathrm{CH}_{2}\right), 4.50\left(2 \mathrm{H}, \mathrm{q},{ }^{3} \mathrm{~J} 7.1, \mathrm{C} \mathrm{CH}_{2}\right), 1.73\left(3 \mathrm{H}, \mathrm{t},{ }^{3} J\right.$ 7.1, $\left.\mathrm{C} \mathrm{CH}_{3}\right), 1.61\left(3 \mathrm{H}, \mathrm{t},{ }^{3} J\right.$ 7.1, $\left.\mathrm{C} \mathrm{CH}_{3}\right)$.

14: ${ }^{1} \mathrm{H}$ NMR $\delta^{1} \mathrm{H}$ 14H $\left(400.13 \mathrm{MHz} ; \mathrm{CDCl}_{3} ; \mathrm{Me}_{4} \mathrm{Si}\right) 7.48(1 \mathrm{H}$, s, H4') 4.55 (2 H, q, ${ }^{3} J$ 7.0, $\left.\mathrm{C}^{\prime} \mathrm{CH}_{2}\right), 4.49$ (2 H, q, ${ }^{3} J$ 7.0, $\left.\mathrm{C}_{6} \mathrm{CH}_{2}\right), 1.74\left(3 \mathrm{H}, \mathrm{t},{ }^{3} \mathrm{~J} 7.1, \mathrm{C} \mathrm{CH}_{3}\right), 1.61\left(3 \mathrm{H}, \mathrm{t},{ }^{3} J\right.$ 7.1, $\left.\mathrm{C}_{6} \mathrm{CH}_{3}\right), 2.88\left(2 \mathrm{H}, \mathrm{t},{ }^{3} \mathrm{~J} 7.3, \mathrm{CH}_{2} \mathrm{CH}_{2} \mathrm{CH}_{2} \mathrm{CH}_{3}\right), 1.75(2 \mathrm{H}, \mathrm{m}$, $\mathrm{CH}_{2} \mathrm{CH}_{2} \mathrm{CH}_{2} \mathrm{CH}_{3}$ ), 1.44 (2 H, tq, ${ }^{3} J$ 7.3, $\mathrm{CH}_{2} \mathrm{CH}_{2} \mathrm{CH}_{2} \mathrm{CH}_{3}$ ), 0.97 (3 H, t, ${ }^{3} J$ 7.3, $\mathrm{CH}_{2} \mathrm{CH}_{2} \mathrm{CH}_{2} \mathrm{CH}_{3}$ ). $\delta^{1} \mathrm{H} 14 \mathrm{Br}\left(400.13 \mathrm{MHz} ; \mathrm{CDCl}_{3}\right.$; $\left.\mathrm{Me}_{4} \mathrm{Si}\right) 4.55\left(2 \mathrm{H}, \mathrm{q},{ }^{3} J\right.$ 7.1, $\left.\mathrm{C} 7 \mathrm{CH}_{2}\right), 4.48\left(2 \mathrm{H}, \mathrm{q},{ }^{3} J\right.$ 7.1, $\left.\mathrm{C} \mathrm{CH}_{2}\right)$, $1.74\left(3 \mathrm{H}, \mathrm{t},{ }^{3} J \mathrm{7.1}, \mathrm{C}_{\mathrm{CH}}\right), 1.60\left(3 \mathrm{H}, \mathrm{t},{ }^{3} \mathrm{~J} 7.1, \mathrm{C} \mathrm{CH}_{3}\right), 2.88$ (2 $\left.\mathrm{H}, \mathrm{t},{ }^{3} \mathrm{~J} 7.2, \mathrm{CH}_{2} \mathrm{CH}_{2} \mathrm{CH}_{2} \mathrm{CH}_{3}\right), 1.74\left(2 \mathrm{H}, \mathrm{m}, \mathrm{CH}_{2} \mathrm{CH}_{2} \mathrm{CH}_{2} \mathrm{CH}_{3}\right.$ ), $1.44\left(2 \mathrm{H}, \mathrm{tq},{ }^{3} \mathrm{~J} 7.2, \mathrm{CH}_{2} \mathrm{CH}_{2} \mathrm{CH}_{2} \mathrm{CH}_{3}\right), 0.97\left(3 \mathrm{H}, \mathrm{t},{ }^{3} \mathrm{~J}\right.$ 7.2, $\mathrm{CH}_{2} \mathrm{CH}_{2} \mathrm{CH}_{2} \mathrm{CH}_{3}$ ).

15: ${ }^{1} \mathrm{H}$ NMR $\delta^{1} \mathrm{H}\left(400.13 \mathrm{MHz} ; \mathrm{CDCl}_{3} ; \mathrm{Me}_{4} \mathrm{Si}\right) 8.74(1 \mathrm{H}, \mathrm{s}$, $\left.\mathrm{H} 4^{\prime}\right), 4.51$ ( $2 \mathrm{H}, \mathrm{q},{ }^{3} J$ 7.1, $\left.\mathrm{C} \mathrm{CH}_{2}\right), 4.48\left(2 \mathrm{H}, \mathrm{q},{ }^{3} J\right.$ 7.2, $\mathrm{C}^{2} \mathrm{CH}_{2}$ ),
5.17 (2 H, q, $\left.{ }^{3} J 6.7, \mathrm{C} 6^{\prime} \mathrm{CH}_{2}\right), 1.74\left(3 \mathrm{H}, \mathrm{t},{ }^{3} J 7.1, \mathrm{C} \mathrm{CH}_{3}\right), 1.63$ (3 $\mathrm{H}, \mathrm{t},{ }^{3} J$ 7.2, $\left.\mathrm{C} \mathrm{CH}_{3}\right), 1.76\left(3 \mathrm{H}, \mathrm{t},{ }^{3} J 7.1, \mathrm{C6}^{\prime} \mathrm{CH}_{3}\right)$.

16: UV-Vis $\lambda_{\max }\left(\mathrm{CH}_{2} \mathrm{Cl}_{2}\right) / \mathrm{nm} 630\left(\varepsilon / \mathrm{dm}^{3} \quad \mathrm{~mol}^{-1} \mathrm{~cm}^{-1}\right.$ $17590), 456$ (38 240), 379 (46 210). FT-IR $\nu_{\mathrm{CO}}$ (hexane) $/ \mathrm{cm}^{-1}$ 2023m $\left(\mathrm{A}_{1}^{(1)}\right)$, 1961s $\left(\mathrm{B}_{1}\right), 1946 \mathrm{~m}\left(\mathrm{~A}_{1}{ }^{(2)}\right), 1894 \mathrm{~m}\left(\mathrm{~B}_{2}\right) .{ }^{\mathbf{1}} \mathbf{H} \mathbf{N M R}$ $\delta^{1} \mathrm{H}\left(300.13 \mathrm{MHz} ; \mathrm{CDCl}_{3} ; \mathrm{Me}_{4} \mathrm{Si}\right) 4.54\left(4 \mathrm{H}, \mathrm{q},{ }^{3} J\right.$ 7.1, $\left.\mathrm{C} \mathrm{CH}_{2}\right)$, 4.47 (4 H, q, ${ }^{3} J$ 7.1, $\left.\mathrm{C} \mathrm{CH}_{2}\right), 1.72\left(6 \mathrm{H}, \mathrm{t},{ }^{3} J \mathrm{~J} .1, \mathrm{C} \mathrm{CH}_{3}\right), 1.62(6$ $\mathrm{H}, \mathrm{t},{ }^{3} J \mathrm{7.1}, \mathrm{C}_{\left.6 \mathrm{CH}_{3}\right) .}{ }^{13} \mathrm{C}$ NMR $\delta^{13} \mathrm{C}\left(100.613 \mathrm{MHz} ; \mathrm{CDCl}_{3}\right.$; $\left.\mathrm{Me}_{4} \mathrm{Si}\right) 286.0$ ( $\mathrm{C}_{\text {carb }}$ ), 280.7 (C6 $\left.6_{\text {carb }}\right), 220.4$ and 219.7 ( $\left.\mathrm{CO}_{\text {trans }}\right)$, $212.0\left(\mathrm{CO}_{\text {cis }}\right.$ ), 169.0 (C5), 162.1 (C4), 137.4 and 133.8 (C3 and C2), $79.7\left(\mathrm{C}_{\mathrm{CH}}\right), 79.6\left(\mathrm{C}^{2} \mathrm{CH}_{2}\right), 14.7\left(\mathrm{C}^{-\mathrm{CH}_{3}}\right.$ and $\left.\mathrm{C}^{2} \mathrm{CH}_{3}\right)$. HR-MS $\mathrm{m} / \mathrm{z}\left(\mathrm{C}_{28} \mathrm{H}_{20} \mathrm{O}_{12} \mathrm{~S}_{3} \mathrm{~W}_{2}, 1012.33 \mathrm{~g} \mathrm{~mol}{ }^{-1}\right)$ calculated: 1010.9058, found: $1010.9023\left(100 \%,[\mathrm{M}-\mathrm{H}]^{-}\right)$, calculated: 982.9109, found: $982.9065\left(16 \%,[\mathrm{M}-\mathrm{H}-\mathrm{CO}]^{-}\right)$, calculated: 954.9159, found: $954.9031\left(6 \%,[\mathrm{M}-\mathrm{H}-2 \mathrm{CO}]^{-}\right)$.

Synthesis of tungsten chelated carbene complexes of dithieno $\left[2,3-b ; 3^{\prime}, 2^{\prime}-\boldsymbol{d}\right]$ thiophene. Compound cis-DTT- $\mathrm{Br}_{4}$ $(1.28 \mathrm{~g}, 2.5 \mathrm{mmol})$ along with $\mathrm{W}(\mathrm{CO})_{6}(1.76 \mathrm{~g}, 5.0 \mathrm{mmol})$ were used in the same reaction as for the preparation of 1-4. Products isolated are listed in Table S5, ESI. $\dagger$

17: ${ }^{1} \mathrm{H}$ NMR $\delta^{1} \mathrm{H}\left(400.13 \mathrm{MHz} ; \mathrm{CDCl}_{3} ; \mathrm{Me}_{4} \mathrm{Si}\right) 4.62$ (4 H, dq, ${ }^{3} J$ 7.1, $\left.\mathrm{C} \mathrm{CH}_{2}\right), 4.50\left(4 \mathrm{H}, \mathrm{dq},{ }^{3} J\right.$ 7.2, $\left.\mathrm{C} 6 \mathrm{CH}_{2}\right), 1.63\left(6 \mathrm{H}, \mathrm{t},{ }^{3} J 7.1\right.$, ${\left.\mathrm{C} 7 \mathrm{CH}_{3}\right),}_{1.53}\left(6 \mathrm{H}, \quad \mathrm{t},{ }^{3} J \quad 7.2,{\left.\mathrm{C} 6 \mathrm{CH}_{3}\right) .}^{13} \mathrm{C} \quad \mathbf{N M R} \delta^{13} \mathrm{C}\right.$ (75.468 MHz; $\left.\mathrm{CDCl}_{3} ; \mathrm{Me}_{4} \mathrm{Si}\right) 296.5$ (C7 $7_{\text {carb }}$ ), 282.9 (C6 $\left.{ }_{\text {carb }}\right), 219.4$ and 216.8 ( $\left.\mathrm{CO}_{\text {trans }}\right), 212.4$ and $210.7\left(\mathrm{CO}_{\text {cis }}\right), 169.0$ (C5), 162.1 (C4), 150.3 and 129.0 (C3 and $\mathrm{C} 2), 80.3\left(\mathrm{C}^{-\mathrm{CH}_{2}}\right), 79.5\left(\mathrm{C}^{2} \mathrm{CH}_{2}\right)$, 14.8 and $14.7\left(\mathrm{C}^{-C_{3}}\right), 14.9$ and $14.9\left(\mathrm{C}^{2} \mathrm{CH}_{3}\right)$.

\section{Characterization and analytical techniques}

Compounds 1 and 2 did not ionize during MS analysis, and therefore the data are neglected. Only proton NMR analysis was carried out on 6, 8, 9, 12, 14 and 15 as the compounds were obtained as an inseparable mixture or were too reactive for further analysis. The reactivity of $\mathbf{4}$ and $\mathbf{1 7}$ allowed only proton and carbon NMR analysis to be obtained, before decomposing.

Nuclear magnetic resonance spectroscopy. NMR spectra were recorded on Bruker Ultrashield Plus 400 AVANCE 3 and Ultrashield 300 AVANCE 3 spectrometers, at $25{ }^{\circ} \mathrm{C}$. The ${ }^{1} \mathrm{H}$ NMR spectra were recorded at 400.13 or $300.13 \mathrm{MHz}$, and the ${ }^{13} \mathrm{C}$ NMR spectra at 100.613 or $75.468 \mathrm{MHz}$, respectively. $\mathrm{CDCl}_{3}$ was used as solvent, and chemical shifts (reported as $\delta$ (ppm) downfield from $\mathrm{Me}_{4} \mathrm{Si}$ ) are referenced at $7.26 \mathrm{ppm}$ for $\delta \mathrm{H}$ and $77.0 \mathrm{ppm}$ for $\delta \mathrm{C}$. Coupling constants $(J)$ are reported in $\mathrm{Hz}$. Preparation of the samples was carried out under $\mathrm{Ar}(\mathrm{g})$ and the NMR tubes were sealed before data collection. The ${ }^{1} \mathrm{H}$ NMR data are reported in the format: chemical shift (integration, multiplicity, coupling constant, assignment) and the ${ }^{13} \mathrm{C}$ NMR data in the format: chemical shift (assignment), in the order of assignments. The spectral coupling patterns are: $\mathrm{s}$ - singlet, $\mathrm{d}$ - doublet, $\mathrm{t}$ - triplet, $\mathrm{q}$ - quartet, $\mathrm{m}$ - multiplet and br - broad.

First-order analysis is carried out to assign signals of the ${ }^{1} \mathrm{H}$ NMR spectra. Additional $2 \mathrm{D}\left[{ }^{1} \mathrm{H},{ }^{1} \mathrm{H}\right]$ COSY NMR experiments were done where confirmation of the proton assignments was required. Assigning the carbon chemical shifts, obtained from 
proton-decoupled ${ }^{13} \mathrm{C}$ NMR spectra, was possible with the assistance of $2 \mathrm{D}\left[{ }^{1} \mathrm{H},{ }^{13} \mathrm{C}\right] \mathrm{HSQC}$ and $2 \mathrm{D}\left[{ }^{1} \mathrm{H},{ }^{13} \mathrm{C}\right] \mathrm{HMBC}$ NMR experiments (see ESI section S3†). Standard Bruker pulse programs were used in the experiments.

Fourier-transform infrared spectroscopy. Infrared spectroscopy was performed on a Bruker ALPHA FT-IR spectrophotometer with a $\mathrm{NaCl}$ cell, using dried hexane as solvent. The absorptions were measured from $400-4000 \mathrm{~cm}^{-1}$. The IR data are reported in the format: absorption intensity (assignment) in the order of highest to lowest wavenumber. The wave intensities are: vw - very weak, w - weak, m - medium, s strong, vs - very strong, sh - shoulder and br - broad.

High-resolution mass spectrometry. Mass spectral analyses were performed on a Waters ${ }^{\circledR}$ Synapt G2 high definition mass spectrometer (HDMS) that consists of a Waters Acquity Ultra Performance Liquid Chromatography (UPLC®) system hyphenated to a quadrupole-time-of-flight (QTOF) instrument. Data acquisition and processing was carried out with MassLynxTM (version 4.1) software. A leucine encephalin solution (2 pg $\mu \mathrm{L}^{-1}, \mathrm{~m} / \mathrm{z} 555.2693$ ) was used as an internal lock mass control standard to compensate for instrumental drift and ensure good mass accuracy. The internal control was directly infused into the source through a secondary orthogonal electrospray ionization (ESI) probe to allowing intermittent sampling. Flow injection analysis (FIA, $0.4 \mathrm{~mL} \mathrm{~min}^{-1}$ flow rate) with the injection volume set at $5 \mu \mathrm{L}$. Samples were made up in ultra-purity liquid chromatography methanol to an approxi-

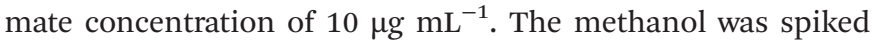
with $0.1 \%$ formic acid and used throughout the $1 \mathrm{~min}$ run. The capillary voltage for the ESI source was set at $2.6 \mathrm{kV}$ for negative mode ionization. The source temperature was set at $110{ }^{\circ} \mathrm{C}$, the sampling cone voltage at $25 \mathrm{~V}$, extraction cone voltage at $4.0 \mathrm{~V}$ and cone gas (nitrogen) flow at $10.0 \mathrm{~L} \mathrm{~h}^{-1}$. The desolvation temperature was set at $300{ }^{\circ} \mathrm{C}$ with a gas (nitrogen) flow of $600.0 \mathrm{~L} \mathrm{~h}^{-1}$. The mass to charge ratios $(\mathrm{m} / \mathrm{z})$ were measured in the range of 50-1500 Da with the raw data presented in the form of a centroid profile (scans collected every 0.3 seconds). A negative electron spray was employed as the ionization technique. The MS data are reported in the format: calculated mass, found mass (percentage intensity, fragmentation) in the order of highest to lowest mass to charge ratio.

\section{UV-Vis spectroscopy}

Measurements were performed on $10 \mathrm{~mL}$ DCM solutions of $0.01 \mathrm{mM}$ analyte concentration at $25{ }^{\circ} \mathrm{C}$. Absorptions were measured in the range $200-1000 \mathrm{~nm}$ using a UV-Vis spectrophotometer Specord 200 plus. WinASPECT PLUS (version 4.2) software was used for data visualization.

\section{X-Ray diffraction analysis}

Single crystal diffraction data for $1,3,5,7,11$ and 16, were collected at $150 \mathrm{~K}$ on a Bruker D8 Venture diffractometer with a kappa geometry goniometer and a Photon 100 CMOS detector using a Mo-K $\alpha$ I $\mu$ S.micro focus source. Data were reduced and scaled using SAINT and absorption intensity corrections were performed using SADABS (APEX III control software). ${ }^{52} \mathrm{~A}$ single crystal of 2 was analyzed on a Rigaku XtaLAB Synergy R diffractometer, with a rotating-anode X-ray source and a HyPix CCD detector. Data reduction and absorption were carried out using the CrysAlisPro (version 1.171.40.23a) software package. ${ }^{53}$ X-ray diffraction measurements were performed at $293 \mathrm{~K}$ using an Oxford Cryogenics Cryostat. All structures were solved by an intrinsic phasing algorithm using SHELXTS ${ }^{54}$ and were refined by full-matrix least-squares methods based on $F^{2}$ using SHELXL. ${ }^{55}$ All non-hydrogen atoms were refined anisotropically. All hydrogen atoms were placed in idealized positions and refined using riding models. The crystal data collection and structure refinement parameters are provided in the ESI. $\dagger$

\section{Cyclic voltammetry}

The cyclic voltammograms were recorded in dry, oxygen-free, high performance liquid chromatography (HPLC) grade DCM using a three-electrode cell. The three electrodes are; the nonaqueous $\mathrm{Ag} / \mathrm{Ag}^{+}$reference electrode, a glassy carbon working electrode and the platinum wire auxiliary (counter) electrode. Measurements were carried out on a Metrohm $\mu$ Autolab type III potentiostat, using NOVA 2.0 electrochemistry software. Measurements were done on $1.0 \mathrm{mM}$ solutions of the compounds that contain $0.1 \mathrm{M}\left[\mathrm{N}^{n} \mathrm{Bu}_{4}\right]\left[\mathrm{PF}_{6}\right]$ as supporting electrolyte, at an scan rates of $100 \mathrm{mV} \mathrm{s}^{-1}$ at $20^{\circ} \mathrm{C}$. $\mathrm{FcH}$ or $\left[\mathrm{Fe}\left(\eta^{5}\right.\right.$ $\left.\mathrm{C}_{5} \mathrm{Me}_{5}\right)_{2}$ ] were used as internal standards $(1.0 \mathrm{mM})$ vs. the $\mathrm{Ag} /$ $\mathrm{Ag}^{+}$couple, with $E^{\circ \prime}=0 \mathrm{~V}$ for the $\mathrm{FcH}^{0 /+1}$ couple and $E^{\circ \prime}=-0.6$ $\mathrm{V}$ for the $\left[\mathrm{Fe}\left(\eta-\mathrm{C}_{5} \mathrm{Me}_{5}\right)_{2}\right]^{0 /+1}$ couple. Compounds 16, 18, 20 and 21 (with $\mathrm{FcH}$ as internal standard) and 1, 3, 11 and 19 (with $\left[\mathrm{Fe}\left(\eta^{5}-\mathrm{C}_{5} \mathrm{Me}_{5}\right)_{2}\right]$ as internal standard) were studied by cyclic voltammetry.

\section{Computational details}

Geometry optimizations of all species discussed in the text were carried out with the GAUSSIAN 09 suite of programs. ${ }^{56}$ Electron correlation was partially taken into account using the B3LYP ${ }^{57-59}$ functional in conjuction with the D3 dispersion correction suggested by Grimme et $a l^{60}$ and the double- $\zeta$ quality plus polarisation functions def2-SVP ${ }^{61}$ basis set for all atoms. This level is denoted (u)B3LYP-D3/def2-SVP. All species were characterized by frequency calculations, ${ }^{62}$ and have positive definite Hessian matrices. Cartesian coordinates (in $\AA$ ) and total energies (in a. u., ZPVE included) of all the stationary points are available in the ESI. $\dagger$

\section{Conflicts of interest}

There are no conflicts to declare.

\section{Acknowledgements}

The authors gratefully acknowledge the National Research Foundation, South Africa (NRF 105740; NRF 105529, NRF 87788 and NRF 9772) and Sasol Technology R\&D Pty. Ltd. 
(South Africa) for financial support. I. F. acknowledges support from the Spanish MINECO (CTQ2016-78205-P, CTQ201681797-REDC and PID2019-106184GB-I00).

\section{References}

1 A. Rajca, M. Miyasaka, M. Pink, H. Wang and S. Rajca, J. Am. Chem. Soc., 2004, 126, 15211.

2 G. M. Tsivgoulis and J.-M. Lehn, Angew. Chem., Int. Ed. Engl., 1995, 34, 1119.

3 Molecular Switches, ed. B. L. Feringa, Wiley-VCH, Weinheim, 2001.

4 M.-C. Chen, Y.-J. Chiang, C. Kim, Y.-J. Guo, S.-Y. Chen, Y.-J. Liang, Y.-W. Huang, T.-S. Hu, G.-H. Lee, A. Facchetti and T. J. Marks, Chem. Commun., 2009, 1846.

5 N. J. Long, Angew. Chem., Int. Ed. Engl., 1995, 34, 21.

6 I. S. Lee, H. Seo and Y. K. Chung, Organometallics, 1999, 18, 5194.

7 C. Q. Ma, Front. Optoelectron., 2011, 4, 12.

8 W. Jiang, Y. Li and Z. Wang, Chem. Soc. Rev., 2013, 42, 6113.

9 S. S. Bukalov, L. A. Leites, K. A. Lyssenko, R. R. Aysin, A. A. Korlyukov, J. V. Zubavichus, K. Y. Chernichenko, E. S. Balenkova, V. G. Nenajdenko and M. Y. Antipin, J. Phys. Chem. A, 2008, 112, 10949.

10 V. G. Nenajdenko, D. V. Gribkov, V. V. Sumerin and E. S. Balenkova, Synthesis, 2003, 124.

11 T. Ozturk, E. Ertas and O. Mert, Tetrahedron, 2005, 61, 11055.

12 K. Y. Chernichenko, E. S. Balenkova and V. G. Nenajdenko, Mendeleev Commun., 2008, 18, 171.

13 S. Roué, H. Sahoune, L. Toupet, J.-F. Halet and C. Lapinte, Organometallics, 2016, 35, 2057.

14 Y. Tanaka, T. Ishisaka, A. Inagaki, T. Koike, C. Lapinte and M. Akita, Chem. - Eur. J., 2010, 16, 4762.

15 J. Barluenga, M. A. Fernández-Rodríguez, E. Aguilar, F. Fernández-Marí, A. Salinas and B. Olano, Chem. - Eur. J., 2001, 7, 3533.

16 R. Stumpf, M. Jaeger and H. Fischer, Organometallics, 2001, 20, 4040.

17 T. S. Powers, W. D. Wulff, J. Quinn, Y. Shi, W. Jiang, R. Hsung, M. Parisi, A. Rahm, X. Wu Jiang, G. P. A. Yap and A. L. Rheingold, J. Organomet. Chem., 2001, 617-618, 182.

18 M. Jaeger, R. Stumpf, C. Troll and H. Fischer, Chem. Commun., 2000, 1, 931.

19 D. B. Grotjahn, F. E. K. Kroll, T. Schäfer, K. Harms and K. H. Dötz, Organometallics, 1992, 11, 298.

20 M. A. Sierra, Chem. Rev., 2000, 100, 3591.

21 M. Landman, R. Pretorius, B. E. Buitendach, P. H. van Rooyen and J. Conradie, Organometallics, 2013, 32, 5491.

22 H. G. Raubenheimer, S. Cronje and C. E. Strasser, Dalton Trans., 2009, 8145.

23 R. L. Beddoes, J. E. Painter, P. Quayle and P. Patel, Tetrahedron, 1997, 53, 17297.
24 N.-A. Weststrate, S. Bouwer, C. Hassenrück, N. A. van Jaarsveld, D. C. Liles, R. F. Winter and S. Lotz, J. Organomet. Chem., 2018, 869, 54.

25 N. A. van Jaarsveld, D. C. Liles and S. Lotz, Dalton Trans., 2010, 39, 5777.

26 N. Hoa Tran Huy, P. Lefloch, J. M. Louis and M. Fetizon, J. Organomet. Chem., 1986, 311, 79.

27 N. Hoa Tran Huy, E. O. Fischer, J. Riede, U. Thewalt and K. H. Dötz, J. Organomet. Chem., 1984, 263, C29-C32.

28 N. Hoa Tran Huy, E. O. Fischer, H. G. Alt and K. H. Dötz, J. Organomet. Chem., 1985, 284, C9-C11.

29 E. O. Fischer, W. Röll, N. Hoa Tran Huy and K. Ackermann, Chem. Ber., 1982, 115, 2951.

30 K. Öfele, F. Dyckhoff and H. G. Krist, Chem. Ber., 1993, 126, 2573.

31 N. Hoa Tran Huy and E. O. Fischer, Nouv. J. Chim., 1985, 9, 257.

32 Z. Lamprecht, N. A. van Jaarsveld, D. I. Bezuidenhout, D. C. Liles and S. Lotz, Dalton Trans., 2015, 44, 19218.

33 F. W. Evans, R. J. Fox and M. Szwarc, J. Am. Chem. Soc., 1960, 82, 6414.

34 M. J. Diem, D. F. Burow and J. L. Fry, J. Org. Chem., 1977, 42, 1801.

35 M. Landman, H. Görls and S. Lotz, J. Organomet. Chem., 2001, 617-618, 280.

36 Z. Lamprecht, S. G. Radhakrishnan, A. Hildebrandt, H. Lang, D. C. Liles, N.-A. Weststrate, S. Lotz and D. I. Bezuidenhout, Dalton Trans., 2017, 46, 13983.

37 D. M. Adams, Metal-Ligand and Related Vibrations, Edward Arnold Publishers Ltd, London, 1967.

38 D. M. Andrada, M. E. Zoloff Michoff, I. Fernández, A. M. Granados and M. A. Sierra, Organometallics, 2007, 26, 5854.

39 I. Fernández, F. P. Cossio, A. Arrieta, B. Lecea, M. J. Mancheño and M. A. Sierra, Organometallics, 2006, 23, 1065.

40 N. Lugan, I. Fernández, R. Brousses, D. A. Valyaev, G. Lavigne and N. A. Ustynyuk, Dalton Trans., 2013, 42, 898.

41 D. A. Valyaev, R. Brousses, N. Lugan, I. Fernández and M. A. Sierra, Chem. - Eur. J., 2011, 17, 6602.

42 B. van der Westhuizen, P. J. Swarts, I. Strydom, D. C. Liles, I. Fernández, J. C. Swarts and D. I. Bezuidenhout, Dalton Trans., 2013, 42, 5367.

43 M. Guricová, T. Tobrman, M. Pižl, S. Žižková, I. Hoskovcová and D. Dvořák, J. Organomet. Chem., 2020, 905, 121023.

44 D. I. Bezuidenhout, B. van der Westhuizen, I. Strydom, P. J. Swarts, J. C. Swarts and I. Fernández, Inorg. Chim. Acta, 2014, 423, 184.

45 G. M. Chu, I. Fernández and M. A. Sierra, Chem. - Eur. J., 2013, 19, 5899.

46 H. Meerwein, Org. Synth., 1966, 46, 113.

47 V. G. Nenajdenko, D. V. Gribkov, V. V. Sumerin and E. S. Balankova, Synthesis, 2003, 1, 124.

48 F. Allared, J. Hellberg and T. Remonen, Tetrahedron Lett., 2002, 43, 1553. 
49 L. Brandsma, S. F. Vasilevsky and H. D. Verkruijsse, Application of transition metal catalysts in organic synthesis, Springer, 1998.

50 L. Yang, P. Ye, W. Li, W. Zhang, Q. Guan, C. Ye, T. Dong, X. Wu, W. Zhao, X. Gu, Q. Peng, B. Tang and H. Huang, Adv. Opt. Mater., 2018, 6, 1.

51 Z. Lamprecht, F. P. Malan, D. C. Liles, S. Lotz and D. I. Bezuidenhout, J. Organomet. Chem., 2020, 925, 121466.

52 APEX3. (including SAINT and $S A D A B S$ ), BrukerAXS Inc., Madison, WI, 2016.

53 Rigaku Oxford Diffraction, Rigaku Corporation, Oxford, UK, 2018.

54 G. M. Sheldrick, Acta Crystallogr., Sect. A: Found. Adv., 2015, 71,3 .

55 G. M. Sheldrick, Acta Crystallogr., Sect. C: Struct. Chem., 2015, 71, 3.

56 M. J. Frisch, G. W. Trucks, H. B. Schlegel, G. E. Scuseria, M. A. Robb, J. R. Cheeseman, G. Scalmani, V. Barone, G. A. Petersson, H. Nakatsuji, X. Li, M. Caricato, A. Marenich, J. Bloino, B. G. Janesko, R. Gomperts, B. Mennucci, H. P. Hratchian, J. V. Ortiz, A. F. Izmaylov, J. L. Sonnenberg, D. Williams-Young, F. Ding, F. Lipparini, F. Egidi, J. Goings, B. Peng, A. Petrone, T. Henderson,
D. Ranasinghe, V. G. Zakrzewski, J. Gao, N. Rega, G. Zheng, W. Liang, M. Hada, M. Ehara, K. Toyota, R. Fukuda, J. Hasegawa, M. Ishida, T. Nakajima, Y. Honda, O. Kitao, H. Nakai, T. Vreven, K. Throssell, J. A. Montgomery Jr., J. E. Peralta, F. Ogliaro, M. Bearpark, J. J. Heyd, E. Brothers, K. N. Kudin, V. N. Staroverov, T. Keith, R. Kobayashi, J. Normand, K. Raghavachari, A. Rendell, J. C. Burant, S. S. Iyengar, J. Tomasi, M. Cossi, J. M. Millam, M. Klene, C. Adamo, R. Cammi, J. W. Ochterski, R. L. Martin, K. Morokuma, O. Farkas, J. B. Foresman and D. J. Fox, et al., Gaussian 09, Revision D.01, Gaussian, Inc., Wallingford CT, 2016.

57 A. D. Becke, J. Chem. Phys., 1993, 98, 5648.

58 C. Lee, W. Yang and R. G. Parr, Phys. Rev. B: Condens. Matter Mater. Phys., 1988, 37, 785.

59 S. H. Vosko, L. Wilk and M. Nusair, Can. J. Phys., 1980, 58, 1200.

60 S. Grimme, J. Antony, S. Ehrlich and H. Krieg, J. Chem. Phys., 2010, 132, 154104.

61 F. Weigend and R. Ahlrichs, Phys. Chem. Chem. Phys., 2005, 7, 3297.

62 J. W. McIver and A. Komornicki, J. Am. Chem. Soc., 1972, 94, 2625. 